\title{
Habitat suitability modelling for sardine Sardina pilchardus in a highly diverse ecosystem: the Mediterranean Sea
}

\author{
Maria Pilar Tugores ${ }^{1}$, Marianna Giannoulaki ${ }^{2, *}$, Magdalena Iglesias ${ }^{1}$, \\ Angelo Bonanno ${ }^{3}$, Vjekoslav Tičina ${ }^{4}$, Iole Leonori ${ }^{5}$, Athanassios Machias ${ }^{2}$, \\ Konstantinos Tsagarakis ${ }^{2}$, Núria Díaz ${ }^{1}$, Ana Giráldez ${ }^{6}$, Bernando Patti ${ }^{3}$, \\ Andrea De Felice ${ }^{5}$, Gualtiero Basilone ${ }^{3}$, Vasilis Valavanis ${ }^{2}$ \\ ${ }^{1}$ Centro Oceanográfico de Baleares, Instituto Español de Oceanografia, Muelle de Poniente s/n, 07015 Palma de Mallorca, \\ Baleares, España \\ ${ }^{2}$ Institute of Marine Biological Resources, Hellenic Centre of Marine Research, PO Box 2214, 71003, Iraklion, Greece \\ ${ }^{3}$ Istituto per l'Ambiente Marino Costiero, Consiglio Nazionale delle Ricerche, Capo Granitola, 91021, \\ Campobello di Mazara (TP), Italy \\ ${ }^{4}$ Institute of Oceanography and Fisheries, Šetalište I. Meštrovi a 63, 21000 Split, Croatia \\ ${ }^{5}$ Istituto di Scienze Marine, Consiglio Nazionale delle Ricerche, Largo Fiera della Pesca, 60125 Ancona, Italy \\ ${ }^{6}$ Centro Oceanográfico de Málaga, Instituto Español de Oceanografía, Puerto Pesquero s/n, 29640 Fuengirola, Málaga, España
}

\begin{abstract}
Integrated information from different parts of the Mediterranean Sea was used to model the spatial and temporal variability of the distribution grounds of the sardine population. Acoustic data from the North Aegean Sea (Eastern Mediterranean), the Adriatic Sea (Central Mediterranean), the Sicily Channel (Central Mediterranean) and Spanish Mediterranean waters (Western Mediterranean) were analysed along with satellite environmental and bathymetric data to model the potential habitat of sardine during summer, autumn and early winter. Generalized additive models were applied in a presence-absence approach. Models were validated in terms of their predictive ability and used to construct maps exhibiting the probability of sardine presence throughout the entire Mediterranean basin as a measure of habitat adequacy for sardine. Bottom depth and sea surface temperature were the environmental variables that explained most of the data variability. Several areas along the Mediterranean coastline were indicated as suitable habitat for sardine in different seasons. An expansion of these areas over the continental shelf, up to $100 \mathrm{~m}$ depth, was consistently noticed from summer to winter. This was attributed to the horizontal movements of sardine related to spawning (i.e. winter period) and the peculiarities of the Mediterranean Sea where areas favouring growth, feeding and spawning processes tend to be localised and prevent a long range, offshore migration as opposed to large upwelling ecosystems. Moreover, within the study period, a positive relationship between the extent of sardine preferred habitat and landings was revealed for both summer and winter seasons throughout the entire Mediterranean Sea.
\end{abstract}

KEY WORDS: Sardine $\cdot$ Habitat suitability modelling $\cdot$ Sardine potential habitat $\cdot$ Potential spawning habitat $\cdot$ Mediterranean Sea $\cdot$ Small pelagic

Resale or republication not permitted without written consent of the publisher

\section{INTRODUCTION}

The Mediterranean Sea has been characterised as a miniature ocean (Lejeusne et al. 2010) and although generally considered as oligotrophic, it is highly heterogeneous in terms of hydrography, bathymetry and productivity. It comprises different kinds of ecosystems, including areas with strong upwelling like the Alboran Sea and the Sicily Channel, closed basins with shallow waters and high productivity like the Adriatic Sea, coastal areas that are under the influence of strong river outflow with subsequent nutri- 
tional forcing and human impact like the North-western Mediterranean, and less productive areas like the Aegean Sea, which is characterised by peculiar topography with many semi-closed basins under the influence of water from the Black Sea. Moreover, the Mediterranean Sea is considered to be a climate transition area and potentially very sensitive to changes in atmospheric forcing (Alcamo et al. 2007).

The European sardine Sardina pilchardus and European anchovy Engraulis encrasicolus comprise the bulk of small pelagic fish catches in the Mediterranean Sea. Along with other fish groups, these small pelagic fish have recently been considered important species by the Global Ocean Ecosystem Dynamics programme (GLOBEC) in terms of population dynamics and the effect of the long-term temperature increase (Barange et al. 2010). Small pelagic fish are known to play a key ecological role in coastal ecosystems, transferring energy from plankton to upper trophic levels (Cury et al. 2000). Their relatively low position in the marine food web, their short life-span and their reproductive strategy of producing large quantities of eggs over extended areas and spawning periods makes them strongly dependent on the environment (Bakun 1996). Understanding the environmental conditions that drive their spatial distribution requires the integration of information over large spatial and temporal scales (Mackinson et al. 1999, Planque et al. 2007).

Sardine fisheries suffer from a high degree of exploitation in many Mediterranean areas. Most stocks exhibit declining trends in terms of abundance and an exploitation rate that often exceeds sustainability (SGMED 2009, 2010). Sardine are known to spawn during winter in the Mediterranean (Olivar et al. 2003, Somarakis et al. 2006, Ganias et al. 2007); thus, early summer lies within the recruitment period for sardine and a large percentage of the species population belongs to the juvenile's fraction. During September, the sardine population can be considered to be fully recruited, whereas early winter coincides with the start of the species' spawning period. Sardines are mainly fished by purse seiners in the Mediterranean Sea, although midwater pelagic trawls also operate in the Adriatic Sea, the Sicily Channel and French coastal waters (Tičina et al. 1999, Lleonart \& Maynou 2003, Basilone et al. 2006, Machias et al. 2008). Both gears operation and fishing practice are based on the spatial detection of major sardine aggregations by means of echosounders. According to the European Common Fishery Policy, in order to maintain the integrity, structure and functioning of ecosystems, the safeguarding of 'essential fish habitats' is necessary. This entails the prerequisite of large-scale fisheries management and underlines the need to examine the relationship between fish spatial distribution and environmental conditions.

Over the last decade, there has been increasing interest in the application of habitat suitability modelling in fisheries science (e.g. Planque et al. 2007, Bellier et al. 2007, Bellido et al. 2008, Giannoulaki et al. 2008, Weber \& McClatchie 2010, Zwolinski et al. 2011). This type of modelling approach links species location information to environmental data, identifying the distribution of species in relation to environmental gradients and providing spatial distribution maps for certain species or life stages.

Following the terminology of Guisan \& Zimmermann (2000), defining the potential habitat of sardine practically means determining the combination of those environmental conditions suitable for the survival of the species in the absence of biotic interactions (i.e. competition or predation, Austin 2002). Spatial patterns of small pelagic fish in the Mediterranean are less well studied compared to those in large upwelling ecosystems (e.g. van der Lingen et al. 2001, Agenbag et al. 2003, Lynn 2003, Castro et al. 2005, Twatwa et al. 2005, Bellier et al. 2007, Planque et al. 2007, Bertrand et al. 2008, Coetzee et al. 2008, Barange et al. 2009, Zwolinski et al. 2010). In the Mediterranean, only regional-scale studies that focus on a particular time of year address this issue (Allain et al. 2001, Giannoulaki et al. 2007, Bellido et al. 2008, Tsagarakis et al. 2008).

Most acoustic surveys routinely applied in the European Mediterranean areas mainly serve stock assessment purposes and are held on a yearly basis in different seasons within the year, depending on the area. Acoustic surveys are known to yield high quality data for habitat modelling, enabling the provision of spatially explicit presence-absence information on species and recording their precise location. Satellite environmental data operate as proxies or surrogates to causal factors, inferring spatial variations of environmental factors. Consequently, they allow the identification of certain combinations of environmental conditions related to preferred habitats because they can provide data at various temporal and spatial scales.

At a meso-scale level, physical processes that are known to increase productivity are considered mostly responsible for the spatial organisation of plankton aggregations and subsequently often drive the spatial distribution of sardine. At a larger scale, the distribution of the sardine population is mostly related to the existing abiotic environmental conditions and the species tolerance limits (e.g. Tičina et al. 2000, Stra- 
toudakis et al. 2006, Bernal et al. 2007, Planque et al. 2007, Bertrand et al. 2008). The present study is the first time that large-scale habitat modelling is applied to adult and spawning sardine in the Mediterranean basin, linking this species' spatial patterns with environmental variables in multiple seasons. One of the major goals and challenges of the current work was to select and implement a model based on data from one part of the Mediterranean Sea that would identify similar, suitable conditions for species occurrence in the entire basin within a particular season. With this in mind, our aim was to avoid over-fitting and instead counterbalance true species' absence and presence in the study areas, evaluating the predicted spatial patterns in other areas by utilizing the existing information from those areas.

To this end, we used satellite environmental and bathymetry data, together with data from acoustic monitoring surveys, in order to (1) describe the environmental conditions that are suitable for sardine presence in the Mediterranean Sea, and (2) identify areas with environmental conditions that meet the potential spatial distribution of sardine in different periods of the year (i.e. June represented early summer, September early autumn and December early winter) and (3) develop annual maps indicating areas suitable for sardine presence.

The annual maps we produced using the above objectives provide a picture of the inter-annual variability of sardine grounds, offering a dynamic aspect of the potential sardine habitat throughout the basin. Furthermore, the temporal persistence of areas indicated as sardine grounds can assist in effective management decisions. We examined the stability of areas with a high probability of sardine presence, as indirect evidence of the importance of certain areas for the stability of the population, and have calculated and mapped an index of habitat persistence (Colloca et al. 2009) for the entire basin. Moreover, the link between the potential habitat of sardine and the related coastal fisheries was evaluated by examining the relationship between the annual variation in the extent of the 'potential habitat area' and the officially reported sardine landings.

Our approach indicates a method to easily obtain information on the temporal changes in the spatial extent of a species' habitat. This is valuable for performing ecological studies, planning acoustic and trawl surveys, reducing the effort required for monitoring population status and implementing effective fisheries management. At the same time, it can set a good framework for understanding the effect of climate on marine ecosystems (Franklin 2009).

\section{MATERIALS AND METHODS}

Five years of acoustic data from 4 different areas of the Mediterranean were assembled and used for habitat modelling purposes: the Spanish Mediterranean waters (Western Mediterranean), the Adriatic Sea (Central Mediterranean), the Sicily Channel (Central Mediterranean) and the North Aegean Sea (Eastern Mediterranean). Surveys were held during June, September and December. Finally, egg survey data collected from the Spanish waters were used to model the potential spawning habitat of sardine for the first time in the Mediterranean Sea.

\section{Study areas}

The Mediterranean Sea is a semi-enclosed area with a single natural connection to the Atlantic Ocean, the Strait of Gibraltar. Its hydrography is highly heterogeneous among the different study areas.

In the Spanish Mediterranean waters (Fig. 1A), the continental shelf is generally narrow, being somewhat wider in the surroundings of the Ebro River. The circulation is dominated by the entrance of less saline Atlantic waters through the Strait of Gibraltar that generate upwelling, resulting in a local enrichment of nutrients and primary production in the Alboran Sea (Champalbert 1996). The Northern Current (NC), a cyclonic along-slope front flowing southwards, and the outflow of freshwater from large rivers (e.g. the Rhone and the Ebro) further characterise these north-western Mediterranean waters.

The Sicily channel connects the 2 major basins of the Mediterranean Sea. It has a fairly narrow (15 nautical mile) continental shelf in the middle of the southern coast but it widens in both the most eastern and most western parts (Fig. 1B, Patti et al. 2004). The surface circulation is controlled by the Modified Atlantic Water motion, the so-called Atlantic-Ionian Stream (AIS, Fig. 1B). The inter-annual variability of the AIS has an impact on the extension of upwelling and the formation of frontal structures (Cuttitta et al. 2003). The generated upwelling is reinforced by windinduced upwelling events (Patti et al. 2004, 2010).

The Adriatic Sea (Fig. 1C) is an elongated basin located in the Central Mediterranean between the Apennine and the Balkan Peninsula. The East Adriatic Current (EAC) dominates the eastern coast and a return flow, the West Adriatic Current (WAC), runs towards the southeast along the western coast. The northern Adriatic is very shallow and gently sloping (average bottom depth of about $35 \mathrm{~m}$ ). The northern 

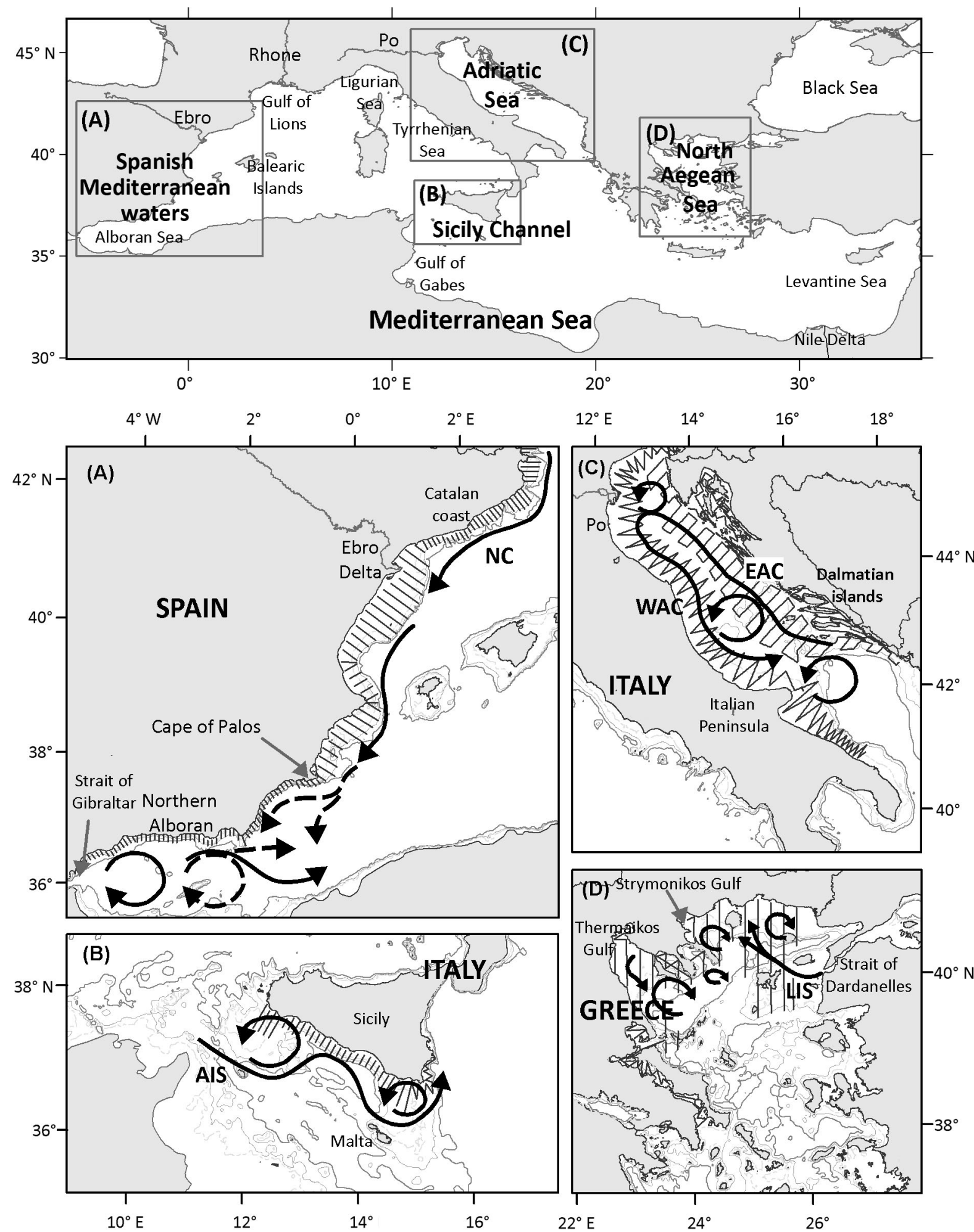

Fig. 1. Study areas within the Mediterranean Sea with insets showing the acoustic sampling transects (thin black lines), bathymetry, positions of main rivers, and water circulation. Arrows indicate the presence of fronts and gyres (redrawn from Millot 1990, Artegianni et al. 1997, Somarakis et al. 2002, Patti et al. 2004). LIS: Limnos-Imvos Stream, NC: Northern Current, AIS: Atlantic-Ionian Stream, WAC: West Adriatic Current, EAC: East Adriatic Current. Toponyms mentioned in the text are 
Adriatic is characterised by a narrow coastal belt along the western coast exhibiting high productivity. The circulation is largely affected by wind stress and river outflows with the formation, particularly in the autumn, of a double gyre structure, a larger cyclone offshore the Po River Delta (Marini et al. 2008) and an anticyclone along the southern Istrian coast (Russo et al. 2009). The eastern coastal waters are generally areas of moderate production with limited zones of higher productivity.

The North Aegean Sea (Fig. 1D) is characterised by high hydrological complexity mostly related to the Black Sea waters (BSW) that enter the Aegean Sea through the Dardanelles Strait as a surface current (Zervakis \& Georgopoulos 2002). The overall circulation is mainly determined by the presence of the Limnos-Imvros Stream (LIS), which carries waters of Black Sea origin onto the Samothraki plateau (Somarakis et al. 2002), generating an anticyclonic system. The outflow of BSW (salinity < 30) enhances local productivity and its advection in the Aegean Sea induces high hydrological and biological complexity (Isari et al. 2006, Somarakis \& Nikolioudakis 2007).

\section{Data collection}

\section{Acoustic sampling}

Acoustic sampling was performed by means of scientific split-beam echosounders (Simrad EK500: western Adriatic Sea and Spanish Mediterranean waters; Simrad EK60: eastern Adriatic, Sicily Channel, Spanish Mediterranean waters since 2006; Biosonic DT-X: North Aegean Sea) working at $38 \mathrm{kHz}$ and calibrated following standard techniques (Foote et al. 1987). Acoustic data were recorded at a constant speed of 8 to $10 \mathrm{n}$ miles $\mathrm{h}^{-1}$. Minimum sampling depth varied between 10 and $30 \mathrm{~m}$ depending on the area. The size of the elementary distance sampling unit (EDSU) was $1 \mathrm{n}$ mile. We considered sardine presence to be any school or echo assigned as a sardine based on either echo trace classification or the catch output of identification hauls (Simmonds \& MacLennan 2005). No discrimination between adults and juveniles was made. Midwater pelagic trawl sampling was used to identify and verify sardine echo traces. Acoustic data analysis was performed using the Myriax Echoview software, or the BI60 SIMRAD software in the case of the Eastern Adriatic.

Specifically, in the Spanish Mediterranean waters acoustic sampling was performed in early winter, between the end of November and the middle of
December from 2003 to 2008, onboard the RV 'Cornide de Saavedra'. Sampling design consisted of parallel equidistant transects that were perpendicular to the bottom depth and covered the continental shelf up to $200 \mathrm{~m}$ depth (Fig. 1A). Inter-transect distance was $4 \mathrm{n}$ miles in the most northern and southern parts where the continental shelf is narrow and $8 \mathrm{n}$ miles in the middle part where the continental shelf is wider. In the Sicily Channel, acoustic data were collected onboard the RV 'Dallaporta' in the month of June from 2003 to 2008. Sampling design consisted of parallel equidistant transects that were perpendicular to the coastline with an inter-transect distance of 5 to $8 \mathrm{n}$ miles, depending on the width of the continental shelf (Fig. 1B).

In the Western Adriatic, acoustic data were collected onboard the RV 'Dallaporta' during September from 2004 to 2008. Acoustic surveys were carried out along predetermined zigzagged transects (Fig. 1C) from 2004 to 2007 (details in Leonori et al. 2007) and along parallel transects perpendicular to the coastline with 8 to $10 \mathrm{n}$ mile inter-transect distance in 2008. In the Eastern Adriatic Sea, acoustic data were collected onboard the RV 'BIOS' during September 2004 to 2008. Acoustic surveys were carried out along predetermined parallel transects with $10 \mathrm{n}$ mile inter-transect distances while transects in the inner part (i.e. between the islands) were positioned according to the topographic features of these areas. Details of the surveys, sampling methodology and data collected have already been described (Tičina et al. 2006; our Fig. 1C). In the North Aegean Sea, acoustic data were collected onboard the RV 'Philia' during June 2004 to 2006 and 2008. Acoustic surveys were carried out along predetermined parallel transects with $10 \mathrm{n}$ mile intertransect distances in open areas while zigzagged transects were sampled inside gulfs (Fig. 1D). Details of the surveys, sampling methodology and data collected in these areas have already been described (Giannoulaki et al. 2008).

\section{Egg sampling}

In the Spanish Mediterranean waters, fish eggs were collected simultaneously with acoustic data using an onboard Continuous Underway Fish Egg Sampler (CUFES, Model C-120, Ocean Instruments) that was installed onboard during early winter from 2006 to 2008. The sampling scheme followed the same transect scheme adopted for the Spanish acoustic surveys. Water was continuously pumped 
from $5 \mathrm{~m}$ below the sea surface through the sampler. The mesh size of the concentrator and collector was $335 \mu \mathrm{m}$. Samples were taken every $3 \mathrm{n}$ miles. If the furthest offshore CUFES station was positive for sardine eggs, the transect was continued further offshore until a null station (i.e. no presence of sardine eggs) was found. The collected eggs were stored in $4 \%$ seawater-buffered formalin solution. Individual fish eggs were visually classified to species and sardine eggs were counted and stored in preservation solution. Sardine-egg concentration along the survey transects was recorded as numbers of eggs per $10 \mathrm{~m}^{3}$.

\section{Environmental data}

Satellite environmental data as well as bathymetry data were used as explanatory variables to model the potential habitat of sardine in the Mediterranean Sea. The Mediterranean is an area well monitored in terms of monthly satellite imagery (summarised in Table 1). Satellite variables were mostly used at the highest resolution available in the online satellite data distribution archives (Table 1) in order to obtain environmental characteristics for each sampling point (Valavanis et al. 2008). This resulted in an average spatial resolution of $1.5 \mathrm{~km}$ (Valavanis et al. 2004), adequately defining environmental spatial heterogeneity in relation to both the applied EDSU of acoustic data and the highest available resolution of the explanatory environmental variables.
Specifically, the sea surface temperature distribution (SST, ${ }^{\circ} \mathrm{C}$ ), the sea surface chlorophyll a concentration (CHLA, $\mathrm{mg} \mathrm{m}^{-3}$ ), the photosynthetically active radiation $\left(P A R\right.$, einstein $\mathrm{m}^{-2} \mathrm{~d}^{-1}$ ), the sea surface salinity distribution (SSS, based on the BCC GODAS model, Behringer \& Xue 2004) and the sea level anomaly (SLA, Cm) were downloaded from respective databases (see Table 1) and the mean environmental monthly values were estimated for all surveyed points concerning June, September and December in each respective year and area. These aforementioned variables might be important either as predictors for food availability or physiological suitability of the habitat, thus having a direct influence on the distribution of sardine echo abundance and eggs (e.g. SST, CHLA) or as proxies for causal factors (Bellido et al. 2001). For example, SLA describe ocean processes such as gyres, meanders and eddies (Pujol \& Larnicol 2005) that enhance productivity and often function as physical barriers differentiating the distribution of species or species' life stages. Indirect factors such as bottom depth (Depth) were also used and were calculated through processing (kriging) of a point data set derived from a blending of depth soundings collected from ships with detailed gravity anomaly information obtained from the Geosat and ERS-1 satellite altimetry missions (Smith \& Sandwell 1997, Table 1). All monthlyaveraged satellite images were processed as regular grids under a GIS environment using ArcInfo GRID software (ESRI 1994).

Table 1. Environmental satellite variables and their characteristics. MODIS: Moderate-resolution Imaging Spectroradiometer, AVHRR: Advanced Very High Resolution Radiometer, SeaWiFS: Sea-viewing Wide Field-of-view Sensor, ERS: Earth-observing satellite, T/P: Topex/Poseidon, GFO: Geosat Follow-On, NCEP: National Centers for Environmental Prediction, EMC: Environmental Modeling Center, CMB: Climate Modeling Branch, GODAS: Global Ocean Data Assimilation System

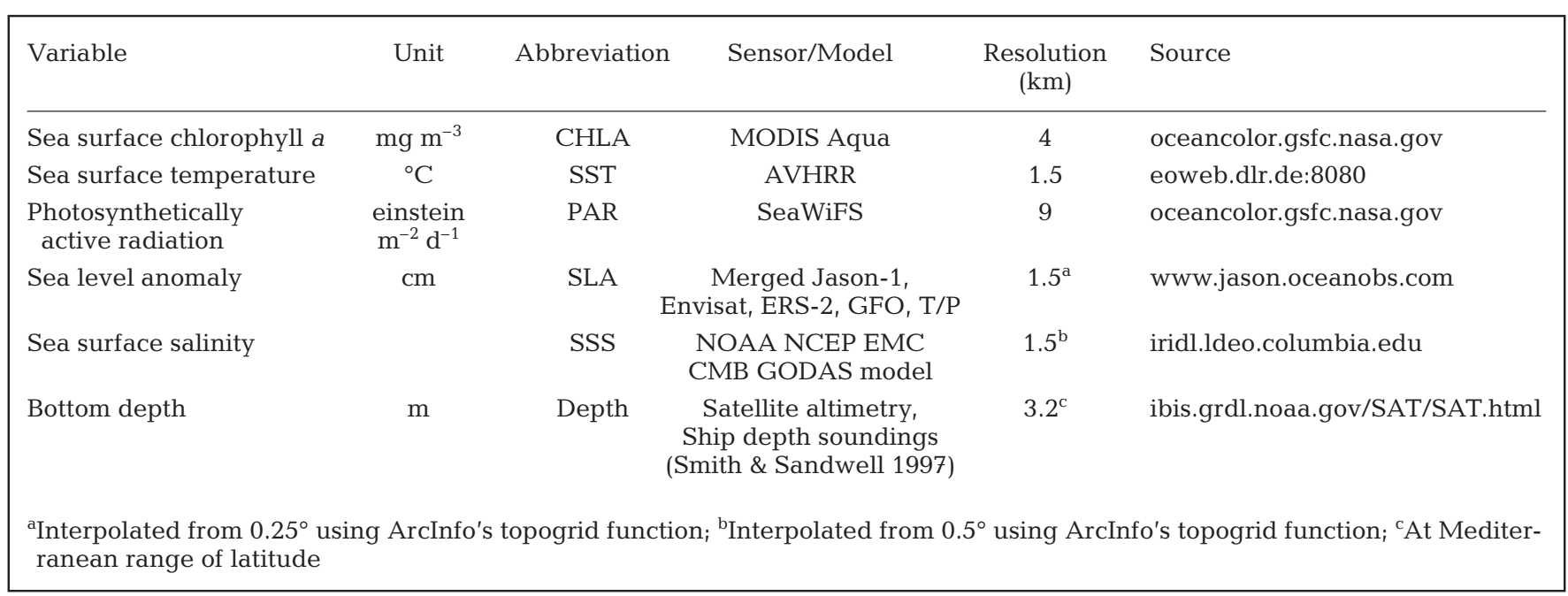




\section{Data analysis}

Model estimation

Generalized Additive Models (GAMs) were used in order to define the set of environmental factors that describe sardine distribution in the North Aegean Sea, Sicily Channel, Adriatic Sea and the Spanish Mediterranean waters. GAMs are widely used in habitat suitability modelling and spatial prediction because they use data-driven functions that have superior performance relative to the polynomial functions used in linear models. They allow the depiction of complex relationships between species and their environment, such as those representing species habitats (Guisan \& Zimmermann 2000). GAMs output a smoothed fit for each environmental variable. Although other methodologies such as boosted regression trees (BRT; Leathwick et al. 2006), associative neural networks (ASNN; Tetko 2002), and maximum entropy modelling (MAXENT; Phillips et al. 2006) are considered models of high predictive capacity, GAMs are known to exhibit high accuracy especially when concerning presence-absence data (Franklin 2009).

As the response variable $(y)$, we used the presenceabsence of sardine echo or sardine eggs. As independent variables we used the cubic root of Depth (to achieve a uniform distribution of bottom depth), the natural logarithm of CHLA (to achieve a uniform distribution of CHLA), the SST, the SSS, the SLA and the PAR. The appropriate type of transformation was based on the inspection of quantile-quantile plots (QQ-plots) to verify whether variables under certain transformations follow normal distributions.

GAMs were fitted using the 'mgcv' library in R statistical software (R Development Core Team 2009), which produced the binomial error distribution, a logit link function and the natural cubic spline smoothed function for the independent variable smoothing. Each fit was analyzed with regard to the minimization of an approximate Akaike's Information Criterion (AIC) and the confidence region for the smooth term (which should not include zero throughout the range of the predictor). Approximate AIC is based on a likelihood that the smooth terms are treated as if they were fixed effects but with degrees of freedom reduced in order to allow smoothing penalties to apply, as suggested in Hastie \& Tibshirani (1990). The degree of smoothing was also chosen based on the observed data and the generalized cross validation (GCV) method (Wood 2006). The GCV method is known to have some tendency for over-fitting, thus the number of knots in the cubic splines was limited to 4 for single terms and 20 for interaction terms. The penalty per degree of freedom fit to each term was increased by a factor of $\gamma=1.4$. This technique largely corrects the over-fitting problem without compromising model fit (Wood 2006, Katsanevakis et al. 2009, Weber \& McClatchie 2010).

Moreover, since collinearity in the independent variables is a crucial problem in GAM application that is associated with stepwise model selection (Guisan et al. 2002, Wood 2006), the best model was chosen based on a stepwise forward selection method that reduces the collinearity problem starting from a simple initial model with few explanatory variables (Sacau et al. 2005, Giannoulaki et al. 2008). Models were compared using the estimated AIC value, environmental variables were ranked and selection of the final model was based on minimization of the AIC criterion.

Regarding adult sardine, 3 models were constructed and validated based on pooled acoustic data derived from (1) the Sicily Channel and the North Aegean Sea in June 2003 to 2008, (2) the eastern and the western parts of the Adriatic Sea in September 2004 to 2008 and (3) the Spanish waters in December 2003 to 2008. Data from the coastal areas inside the gulfs of the Eastern Adriatic were excluded from the analysis due to the poor satellite data resolution in these locations. Regarding sardine spawning habitat, a model was constructed based on pooled CUFES data from 2006 to 2008 derived from Spanish Mediterranean waters in December. Data from the different years were collated in order to catch the temporal variability in sardine distribution area, obtain more possible observed conditions and ensure potentiality (Planque et al. 2007, Giannoulaki et al. 2008, Zwolinski et al. 2011). Following the selection of the main effects of the model, all first-order interactions between variables included in the final model were tested (Wood 2006). Validation graphs (e.g. residual plot versus fitted values, QQ-plot and residual plot against the original explanatory variables) were plotted in order to detect model misspecification.

Acoustic data recorded continuously along transects are known to present autocorrelation. Spatial autocorrelation is known to inflate the ability of models to make realistic predictions favouring autocorrelated variables (Segurado et al. 2006), although GAMs are not influenced that much by the effect of autocorrelation when compared to other methodologies like generalized linear models (GLMs, Segurado et al. 2006). However, in order to avoid this effect, we adjusted the Type I error rate by setting the accepted significance level for each term at the more conservative value of $1 \%$, rather than the usual 5\% (Fortin \& Dale 2005). 
Finally, to exclude the possibility of fitting a model for which the explanatory power arises from the presence of spatial correlation in the data rather than from a true distribution-to-environment relationship (DinizFilho et al. 2003) as well as to evaluate the lack of important explanatory variables (Barry \& Elith 2006), the models' residuals were tested for autocorrelation using variography (Chilés \& Delfiner 1999).

\section{Model validation}

In a subsequent step, each final model was tested and evaluated for its predictive performance. For this purpose, we estimated the receiver operating characteristic (ROC) curve (Hanley \& McNeil 1982, Guisan \& Zimmermann 2000) and the area under the curve (AUC) metric. AUC is a threshold-independent metric, widely used in species' distribution modelling (Franklin 2009, Weber \& McClatchie 2010). The value of AUC ranges from 0 to 1 , where a score of 1 indicates perfect discrimination and a score of 0.5 implies predictive ability that is no better than a random guess (Boyce et al. 2002, Elith et al. 2006). AUC values of 0.7 to 0.9 are considered moderate and $>0.9$ high model performance (Franklin 2009). Additionally, sensitivity (i.e. the proportion of observed positives that are correctly predicted) and specificity values (i.e. the proportion of observed negatives that are correctly predicted) were also used for model evaluation (Lobo et al. 2008). They were measured in relation to 2 threshold criteria: (1) the maximization of the specificity-sensitivity sum (MDT) and (2) the prevalence values (JiménezValverde et al. 2008, Lobo et al. 2008).

The explanatory power of each model was checked for consistency throughout the surveys to ensure that a single or small number of surveys did not dominate the relationships. Using the best fitted model (i.e. a single model fit with all data), AUC values were estimated for each data set to provide such diagnostics. Large and consistent AUC values suggest a model with accurate and time-invariant prediction capabilities. Therefore, all metrics were estimated for areas and years included in the model selection as well as for areas and periods not included in model selection, such as (1) the Spanish Mediterranean waters in December 2003, (2) the Sicilian Channel in June 2003, (3) the North Aegean Sea in June 2010, (4) the Spanish Mediterranean waters in June 2009, (5) the western Adriatic Sea in September 2004 and 2005, (6) the eastern Adriatic Sea in September 2004 and (7) the Spanish Mediterranean waters in December 2009 concerning the egg model.

\section{Habitat mapping}

The final GAM model for each period was applied to new environmental grids describing the mean monthly satellite values measured for the entire Mediterranean basin, re-sampled at a spatial resolution of $4 \mathrm{~km}$ for June, September and December from 2004 to 2008. Although the model was fitted at a finer resolution $(1.5 \mathrm{~km})$, it was re-projected at a coarser grid (about 2.5 times coarser). The error was considered minimal since the available satellite data derived from a single optimum resolution (see Table 1) that minimizes the interpolation error and practically provides very similar values for the variables at any particular point in space for the 2 grids. This was considered a reasonable trade-off between the patterns identified by the model and the computer power required to map the resulted probabilities at the scale of the Mediterranean Sea.

The model was used to search over these grids for the specific set of satellite conditions associated with different probabilities of sardine or sardine egg presence. Finally, habitat suitability maps indicating the locations with this specific set of satellite conditions were plotted as maps using the ArcGIS software. Discrimination is presented among (1) sardine basin habitat (i.e. A025: the wider distribution area of sardine or the area represented by probability $>0.25$ ), (2) the preferred sardine habitat (i.e. A050: areas of increased likelihood of suitable environmental conditions, represented by probability $>0.50$ ), and (3) 'hotspot' areas (i.e. A075: areas of high probability of suitable conditions for sardine's presence, indicated by values $>0.75)$.

Additionally, maps indicating areas that persistently corresponded to sardine preferred habitat within the study period were drawn. For this purpose, we calculated an index of persistence $\left(I_{i k j}\right)$ for each grid cell of the entire Mediterranean Sea and each sampling season, measuring the relative persistence of the cell $i$ as a seasonal sardine habitat (Colloca et al. 2009). Let $\delta_{i k j}=1$ if the grid cell $i$ is included in sardine habitat in year $j$, and season $k$ and $\delta_{i k j}=0$ if the grid cell is not included. We computed $I_{i k j}$ as follows:

$$
I_{i k j}=\frac{1}{n} \sum_{k=1}^{n} \delta_{i k j}
$$

where $n$ is the number of surveys considered. $I_{i k j}$ ranges between 0 (cell $i$ never included in an annual sardine habitat) and 1 (cell $i$ always included in an annual sardine habitat area) for each cell in the study area.

No persistency maps were plotted in the case of sardine eggs due to the short time series available. 


\section{Sardine catches versus potential habitat changes}

The relationship between the extent of the area of the potential sardine habitat with increased likelihood of suitable environmental conditions (i.e. the number of grid cells corresponding to A050 area) and the officially reported annual sardine catches for the 2004-2008 period from the entire Mediterranean Sea (FAO 2010) during June and December was examined. The integration of information deriving from the entire basin instead of relying on specific area information was considered necessary as any area separation would be arbitrary, especially regarding the determination of the origin of landings and the lack of data from vessel monitoring systems. Besides, to a certain degree, landings are known to be representative of stock abundance, especially when high exploitation or overexploitation occurs (Coll et al. 2006) as the current status of most sardine stocks in the Mediterranean indicates (SGMED 2009, 2010). In support of this, in an area like the Mediterranean where small pelagic species like sardine are known to perform extended alongshore migrations and many small pelagic stocks are under shared exploitation, the meaning of stock units remains obscure.

\section{RESULTS}

\section{Satellite environmental data}

Variability in the satellite environmental data concerning the Mediterranean basin for the examined period was observed to be most pronounced in SST and CHLA values (Fig. 2). Specifically, SST showed consistently higher values in the southern part of the basin. This pattern was more pronounced during September (Fig. 2). CHLA exhibited the reverse pattern with higher values in the north of the Mediterranean basin (Fig. 2). Moreover, between the western and eastern parts of the basin, variability in CHLA was apparent, being higher in the west compared to the east part of the Mediterranean, which was in agreement with the known productivity gradient in the basin (Barale et al. 2008).

\section{Habitat modelling \\ Model estimation}

The results of the final GAMs selected are presented in Table 2, and the effects of the environmen- tal variables on sardine presence are shown as plots of the fitted smooth functions (Fig. 3). For the main effects the $95 \%$ confidence intervals (CIs) are also plotted. Interaction effects are shown as perspective plots without error bounds. The $y$-axis of the interaction plots reflects the relative importance of each variable in the model and the interaction effect is presented on the $z$-axis. The dashes on the $x$-axis under the single variable effect plots, so called 'rug', indicates the density of points for the $x$-values. The effect of each variable is a conditional effect, i.e. the effect of this variable given that the other variables are included in the model. Inspection of the validation graphs (not shown) indicated a distinct pattern regarding the plot of residual versus fitted values due to the presence-absence nature of the data (no indication of a lack of fit). Deviance explained varied from $30 \%$ to $43 \%$ of the total data deviance depending on the model (Table 2).

\section{June sardine model}

The final GAM selected for this month was based on pooled data from the North Aegean Sea and the Sicily Channel from 2004 to 2008 and included the following as main effects: SST, Depth (cube-root transformed bottom depth) and the interactive effect of SLA with CHLA (log transformed). SST is the variable that initially entered the model and explained most of the total variation (Table 2). Plots of the smoothed functions indicate a higher probability of finding sardine present in areas with SST values below $22^{\circ} \mathrm{C}$ (within the available values) and depths less than $65 \mathrm{~m}$ and a sharply reduced probability in deeper waters. The interaction plot between SLA and CHLA also indicates a higher probability of finding sardine present in areas with SLA values of -10 to $-4 \mathrm{~cm}$ that also have CHLA values of 0.08 to $0.37 \mathrm{mg}$ $\mathrm{m}^{-3}$ (Fig. 3). A high probability for sardine presence was also indicated for areas with SLA values of -3 to $0 \mathrm{~cm}$ that also have high CHLA values $\left(>1 \mathrm{mg} \mathrm{m}^{-3}\right)$.

\section{September sardine model}

The final GAM selected to model this month was based on pooled data from the western and the eastern parts of the Adriatic Sea from 2004 to 2008 and included the interactive effect of depth (cubic root transformed) with SST as well as the interactive effect of SLA with CHLA (log transformed). Depth is the variable that was initially entered into the model, 


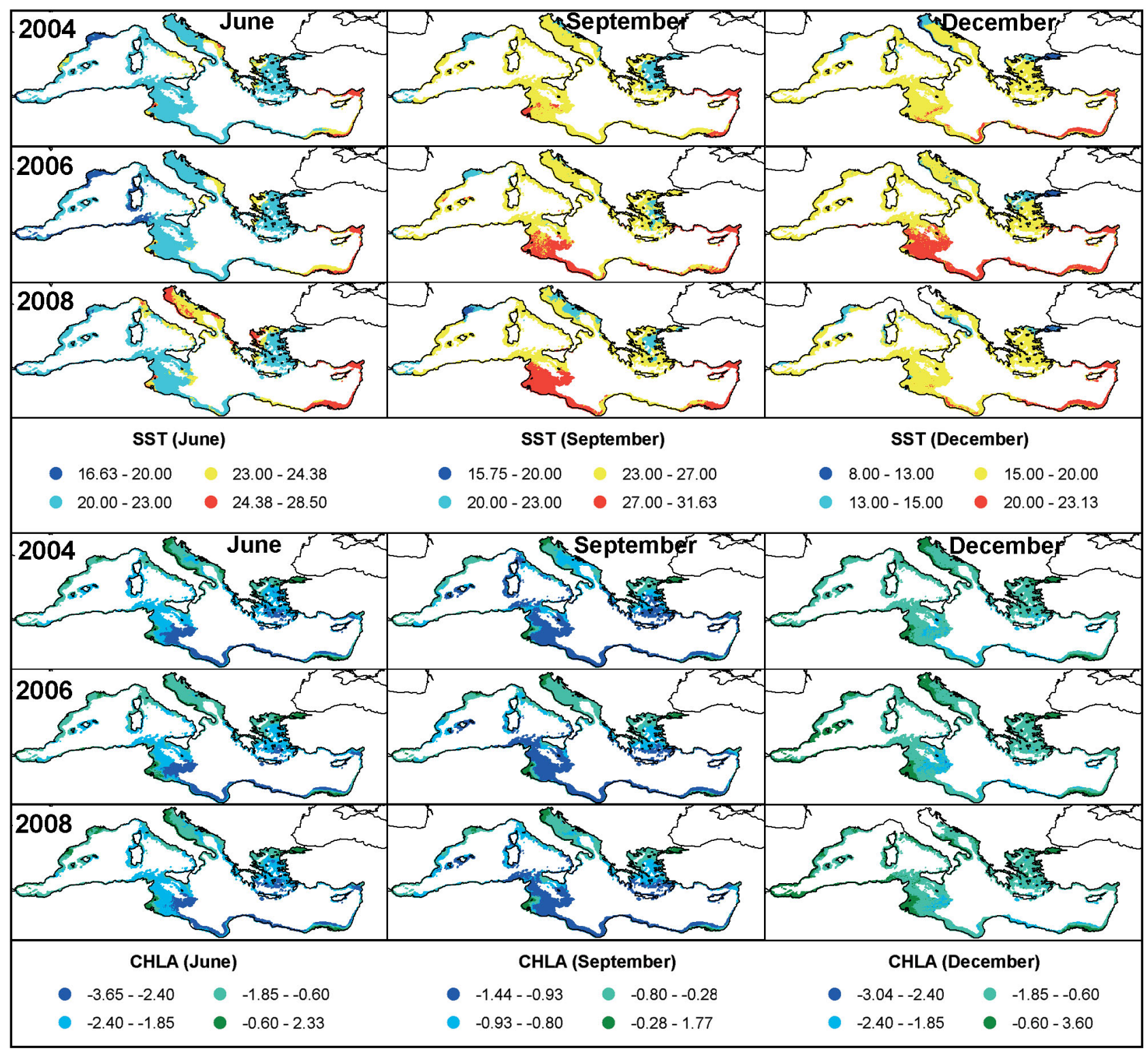

Fig. 2. Spatial distribution of (top panels) sea surface temperature (SST, ${ }^{\circ} \mathrm{C}$ ) over the ocean's upper $5 \mathrm{~m}$ and (lower panels) chlorophyl a (log-transformed CHLA, $\mathrm{mg} \mathrm{m}^{-3}$ ) during June, September and December in the Mediterranean over the study period based on satellite environmental data

Table 2. Sardina pilchardus. Generalized additive model (GAM) results for sardine adults and eggs showing the analysis of deviance for GAM covariates and the interactions of the final models fitted. See Table 1 for parameter descriptions

\begin{tabular}{|c|c|c|c|c|c|c|}
\hline Area & Month & Parameter & $\begin{array}{l}\text { Residual } \\
\text { df }\end{array}$ & $\begin{array}{l}\text { Residual } \\
\text { deviance }\end{array}$ & $\begin{array}{c}\text { Deviance } \\
\text { explained (\%) }\end{array}$ & $\mathrm{p}$ \\
\hline $\begin{array}{l}\text { Sicily Channel \& North } \\
\text { Aegean Sea, pooled }\end{array}$ & June & $\mathrm{s}(\mathrm{SLA}, \mathrm{CHLA})+\mathrm{s}(\mathrm{SST})+\mathrm{s}($ Depth $)$ & 3461.42 & 2923.80 & 31.5 & $\ll 0.000$ \\
\hline Adriatic Sea & September & $($ Depth, SST $)+$ s(SLA, CHLA $)$ & 8209.94 & 5730.90 & 31.7 & $\ll 0.000$ \\
\hline $\begin{array}{l}\text { Spanish Mediterranean } \\
\text { waters }\end{array}$ & December & $\mathrm{s}($ Depth $)+\mathrm{s}(\mathrm{CHLA})+\mathrm{s}(\mathrm{SLA}, \mathrm{SST})$ & 4766.67 & 4624.58 & 30.5 & $\ll 0.000$ \\
\hline $\begin{array}{l}\text { Spanish Mediterranean } \\
\text { waters, eggs }\end{array}$ & December & $\mathrm{s}(\mathrm{CHLA}, \mathrm{SST})+\mathrm{s}(\mathrm{SLA})+\mathrm{s}($ Depth $)$ & 729.13 & 537.56 & 43.0 & $\ll 0.000$ \\
\hline
\end{tabular}



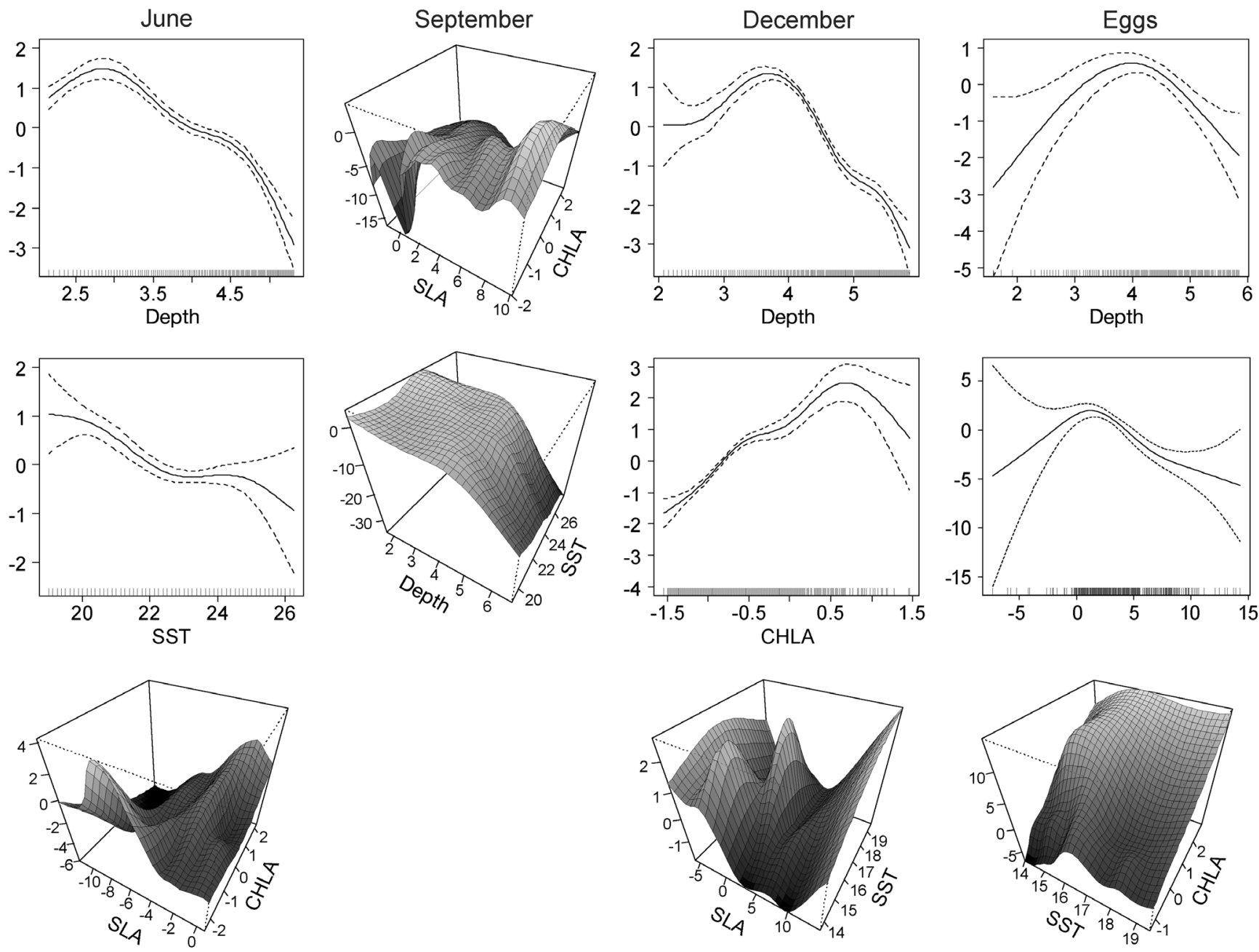

Fig. 3. Sardina pilchardus. Two-dimensional coefficients of the generalized additive models (GAMs) and 3-dimensional interaction plots for each estimated model. The $y$-axis of the interaction plots reflects the relative importance of each variable in the model and the interaction effect is presented on the $z$-axis. The dashes on the $x$-axis under the single variable effect plots, so called 'rug', indicates the density of points for the $x$-values. Solid lines indicate the GAM coefficients, and dotted lines represent the $95 \%$ point-wise confidence bands at $\mathrm{p}=0.05$. See Table 1 for parameter descriptions

explaining most of the total variation (Table 2). Plots of the smoothed best-fit functions indicate a higher probability of finding sardine present in areas with SST values of 20 to $26^{\circ} \mathrm{C}$ and in waters less than $110 \mathrm{~m}$ deep. The interaction plot between SLA and CHLA also indicates a higher probability of finding sardine present in areas with SLA values of 2 to $10 \mathrm{~cm}$ that also have CHLA values of 0.13 to $1.49 \mathrm{mg}$ $\mathrm{m}^{-3}$ (Fig. 3).

December sardine model

The final GAM selected for this season was based on pooled data from the Spanish Mediterranean waters from 2004 to 2008 and included the following variables as main effects: Depth (cubic root transformed), CHLA (log transformed) as well as the interactive effect of SLA with SST. Depth is the variable initially entered into the model, explaining most of the total variation (Table 2). Plots of the smoothed functions indicate a higher probability of finding sardine present in areas with CHLA values greater than $0.45 \mathrm{mg} \mathrm{m}^{-3}$ and less than $4.5 \mathrm{mg} \mathrm{m}^{-3}$ (within the available ones) and in waters less than $90 \mathrm{~m}$ deep. The interaction plot between SLA and SST also indicates a higher probability of finding sardine present in areas with SST values of 14 to $17^{\circ} \mathrm{C}$ that also have SLA values of -5 to $0 \mathrm{~cm}$ (Fig. 3). Moreover, a high probability of sardine presence was also indicated for areas with SST values of 16 to $18.5^{\circ} \mathrm{C}$ that also have SLA values of 1 to $5 \mathrm{~cm}$. 
December sardine egg model

The final GAM selected was based on pooled egg data from the Spanish Mediterranean waters from 2006 to 2008 and included the following as main effects: Depth (cubic root transformed) and SLA as well as the interactive effect of CHLA (log transformed) with SST. SST is the variable initially entered into the model, explaining most of the total variation (Table 2). Plots of the smoothed functions indicate a higher probability of finding sardine eggs present in areas with SLA values greater than $-1.5 \mathrm{~cm}$ and less than $4.9 \mathrm{~cm}$ (within the available ones) and in waters between 30 and $110 \mathrm{~m}$ deep. The interaction plot between CHLA and SST also indicates higher probability of finding sardine eggs present in areas with SST values of 14 to $17^{\circ} \mathrm{C}$ when
CHLA values are within 1 to $2.7 \mathrm{mg} \mathrm{m}^{-3}$ (Fig. 3). These results do not deviate from the respective adult model results in December. They indicate a wider depth range for the eggs that could be attributed to dispersion processes whereas CHLA, SST and SLA are within a similar, slightly narrower range of values compared to those indicated by the adult model.

\section{Model validation}

Each model was evaluated based on the estimated AUC values as well as the sensitivity and specificity values in relation to 2 threshold criteria. Areas and years included in the model estimation as well as areas and years that were not included in the GAM

Table 3. Sardina pilchardus. Validation parameters for sardine GAM models fitted to satellite-derived environmental variables from the Mediterranean Sea including estimated area under the receiver operating curve (AUC) and sensitivity and specificity accuracy measures for 2 threshold criteria: (1) maximized specificity-sensitivity sums (MDT) and (2) prevalence values.

Bold: data from areas or years not included in the model selection

\begin{tabular}{|c|c|c|c|c|c|c|c|c|}
\hline \multirow[t]{2}{*}{ Month } & \multirow[t]{2}{*}{ Year } & \multirow[t]{2}{*}{ Area } & \multirow[t]{2}{*}{$\mathrm{N}$} & \multirow[t]{2}{*}{ AUC } & \multicolumn{2}{|c|}{$\longrightarrow \mathrm{MDT}-$} & \multicolumn{2}{|c|}{ — Prevalence- } \\
\hline & & & & & Sensitivity & Specificity & Sensitivity & Specificity \\
\hline \multirow{9}{*}{ June } & 2004 & North Aegean Sea & 510 & 0.78 & 0.69 & 0.75 & 0.51 & 0.85 \\
\hline & 2005 & North Aegean Sea & 555 & 0.73 & 0.71 & 0.71 & 0.85 & 0.42 \\
\hline & 2006 & North. Aegean Sea & 1044 & 0.73 & 0.72 & 0.67 & 0.69 & 0.69 \\
\hline & 2008 & North Aegean Sea & 358 & 0.76 & 0.69 & 0.77 & 0.91 & 0.41 \\
\hline & 2005 & Sicily Channel & 514 & 0.78 & 0.68 & 0.87 & 0.75 & 0.72 \\
\hline & 2006 & Sicily Channel & 516 & 0.78 & 0.90 & 0.76 & 0.60 & 0.90 \\
\hline & 2010 & North Aegean Sea & 376 & 0.71 & 0.55 & 0.71 & 0.55 & 0.64 \\
\hline & 2003 & Sicily Channel & 478 & 0.62 & 0.78 & 0.51 & 0.19 & 0.92 \\
\hline & 2009 & North Spanish Medit. & 320 & 0.65 & 0.73 & 0.57 & 0.60 & 0.65 \\
\hline \multirow{11}{*}{ September } & 2004 & West Adriatic & 1005 & 0.82 & 0.78 & 0.77 & 0.94 & 0.44 \\
\hline & 2004 & East Adriatic & 865 & 0.76 & 0.93 & 0.57 & 0.47 & 0.83 \\
\hline & 2005 & West Adriatic & 1439 & 0.82 & 0.81 & 0.49 & 0.20 & 0.78 \\
\hline & 2006 & West Adriatic & 1425 & 0.94 & 0.95 & 0.86 & 0.95 & 0.64 \\
\hline & 2006 & East Adriatic & 1094 & 0.85 & 0.75 & 0.84 & 0.98 & 0.58 \\
\hline & 2007 & West Adriatic & 1399 & 0.87 & 0.79 & 0.92 & 0.78 & 0.85 \\
\hline & 2007 & East Adriatic & 1088 & 0.89 & 0.93 & 0.70 & 0.93 & 0.65 \\
\hline & 2008 & West Adriatic & 634 & 0.81 & 0.92 & 0.54 & 0.20 & 0.78 \\
\hline & 2008 & East Adriatic & 1069 & 0.90 & 0.96 & 0.71 & 0.77 & 0.82 \\
\hline & 2006 & South-west Adriatic & 404 & 0.83 & 0.79 & 0.77 & 0.79 & 0.77 \\
\hline & 2007 & South-west Adriatic & 510 & 0.84 & 0.77 & 0.75 & 0.78 & 0.74 \\
\hline \multirow[t]{6}{*}{ December } & 2003 & North \& South Spanish Medit. & 1264 & 0.77 & 0.86 & 0.59 & 0.75 & 0.68 \\
\hline & 2004 & North \& South Spanish Medit. & 1090 & 0.81 & 0.74 & 0.76 & 0.75 & 0.75 \\
\hline & 2005 & North \& South Spanish Medit. & 1090 & 0.85 & 0.80 & 0.77 & 0.70 & 0.84 \\
\hline & 2006 & North \& South Spanish Medit. & 952 & 0.88 & 0.77 & 0.85 & 0.79 & 0.82 \\
\hline & 2007 & North Spanish Medit. & 669 & 0.87 & 0.90 & 0.73 & 0.86 & 0.76 \\
\hline & 2008 & North \& South Spanish Medit. & 998 & 0.77 & 0.78 & 0.65 & 0.85 & 0.56 \\
\hline \multirow[t]{4}{*}{ Eggs } & 2006 & North \& South Spanish Medit. & 281 & 0.82 & 0.97 & 0.54 & 0.78 & 0.65 \\
\hline & 2007 & North \& South Spanish Medit. & 186 & 0.83 & 0.80 & 0.71 & 0.80 & 0.71 \\
\hline & 2008 & North \& South Spanish Medit. & 294 & 0.93 & 0.83 & 0.98 & 0.87 & 0.85 \\
\hline & 2009 & North \& South Spanish Medit. & 312 & 0.63 & 0.65 & 0.61 & 0.62 & 0.64 \\
\hline
\end{tabular}


estimation were considered. Results are shown in Table 3. The selected models showed moderate to good prediction ability as the estimated AUC, sensitivity and specificity values were on average $>0.70$ (Table 3; Elith et al. 2006, Segurado et al. 2006). Moreover, the validation results for 2009 and 2010, years outside the study period, showed low AUC values (Table 3). This result is mostly due to a high increase in SST (i.e. $0.5^{\circ} \mathrm{C}$ to $1^{\circ} \mathrm{C}$ ) compared to the average SST of the study period. However, the sensitivity-specificity values estimated at 0.65 indicate that the model, at a threshold chosen based on the prevalence sensitivity and specificity values can still attribute more than $60 \%$ of the true presence and the true absence accurately.

\section{Habitat mapping}

In a subsequent step, habitat suitability maps for the study regions and the entire Mediterranean Sea were estimated for June, September and December 2004 to 2008 (Figs. 4, 5 \& 6) where areas associated with a specific probability of suitable conditions for sardine presence are indicated. Annual variability was observed in all study regions concerning the areas indicated as potential sardine habitat (A025, A050 and A075).

An increase in the extent of the suitable areas (A050) was generally observed from June to December. In Spanish Mediterranean waters, maps indicated suitable areas for sardine habitat in the coastal waters of the Catalan Sea, the south Ebro River and the North Alboran Sea (Figs. 4, 5 \& 6). In the Adriatic Sea, suitable areas for sardine were indicated in the coastal waters of the eastern and the western part of the basin. Areas presenting the highest suitability increased progressively from June to December, covering most of the continental shelf at the North Adriatic Sea during late autumn (Figs. 4, 5 \& 6). The observed absence of suitable areas in the northern part of the Adriatic Sea in December 2008 is due to the lack of satellite data for this month. In the Sicily Channel, suitable areas were also identified in the coastal waters of the continental shelf, being more extended in the southwestern part and in the shelf between Sicily and Malta (Figs. 4, 5 \& 6). Similarly, in the Aegean Sea, suitable areas for sardine were mainly located in the coastal waters of the continental shelf, covering most of the gulfs that dominate the Greek coastline (Figs. 4, 5 \& 6). Besides the study areas, habitat suitability maps indicated suitable areas in other parts of the western and eastern
Mediterranean as well as in various areas of the coastal waters of Africa (Figs. 4, 5 \& 6).

Similarly, based on the potential spawning habitat (PSH) maps during early winter, areas suitable for sardine spawning were consistently identified in the surroundings of the Ebro River Delta and the North Alboran Sea (Figs. 1 \& 7), a pattern that matches the former sardine spawning grounds in the Spanish Mediterranean waters (Pérez de Rubín 1996, Olivar et al. 2003, Vargas-Yáñez \& Sabatés, 2007). Suitable spawning areas visually correspond to sardine adult potential distributions, which agrees with the coincidence between early winter and the beginning of the spawning season for sardine in the Mediterranean (García et al. 2006 and references therein, Somarakis et al. 2006). PSH areas were also indicated in other parts of the Mediterranean as well as in the coastal waters of Africa (Fig. 7).

Maps for the entire Mediterranean were estimated for June, July, September and December, indicating the index of persistence (Colloca et al. 2009) for each potential habitat grid cell. Areas with A050 probability of sardine presence at a low persistency (i.e. $25 \%$ to $50 \%$ ), intermediate (i.e. $50 \%$ to $75 \%$ ) and high persistency (i.e. $>75 \%$ ) are shown (Fig. 8). The resulting maps indicate that although the spatial extent of areas with a high probability of sardine presence might vary on an annual basis, there are areas that are quite persistently identified as potential habitats (Fig. 8). Persistently favourable areas were almost consistently associated with river runoff, such as the Ebro and the Rhone Rivers in the Western Mediterranean, the Po River in the north-western part of the Adriatic Sea and the Nile Delta region during all seasons, as well as with upwelling areas such as the coastal waters of the Alboran Sea and the southern coasts of Sicily (Fig. 8).

\section{Sardine catches versus potential habitat area}

Sardine annual catches from the entire Mediterranean basin based on officially reported data from the FAO were significantly related to the A050 area (i.e. area of increased probability of suitable environmental conditions for sardine presence) in December (Fig. 9a). Results showed that sardine catches decreased when a decrease in the estimated potential habitat area A050 was observed during December. Sardine catches were also significantly related to sardine potential habitat area A050 during June, representing a 1 year lag (Fig. 9b) and thus decreasing when a decrease of the A050 area in the previous year was observed. 


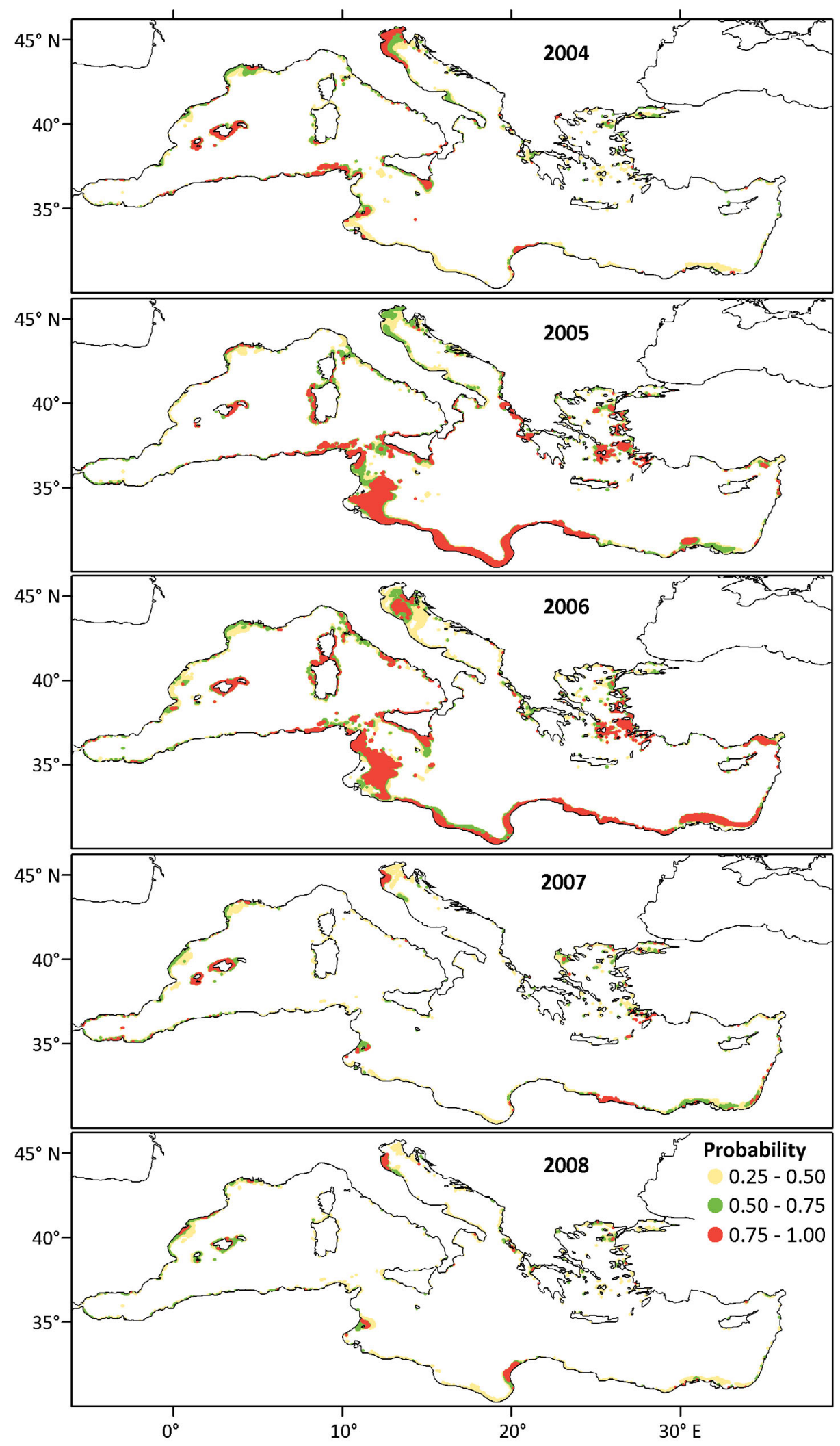

Fig. 4. Sardina pilchardus. Habitat suitability maps indicating the probability of sardine presence in the Mediterranean Sea in early summer based on the estimated GAM model for June. Spatial resolution used for prediction was $4 \mathrm{~km}$ of mean monthly satellite values from June 2004 to 2008 


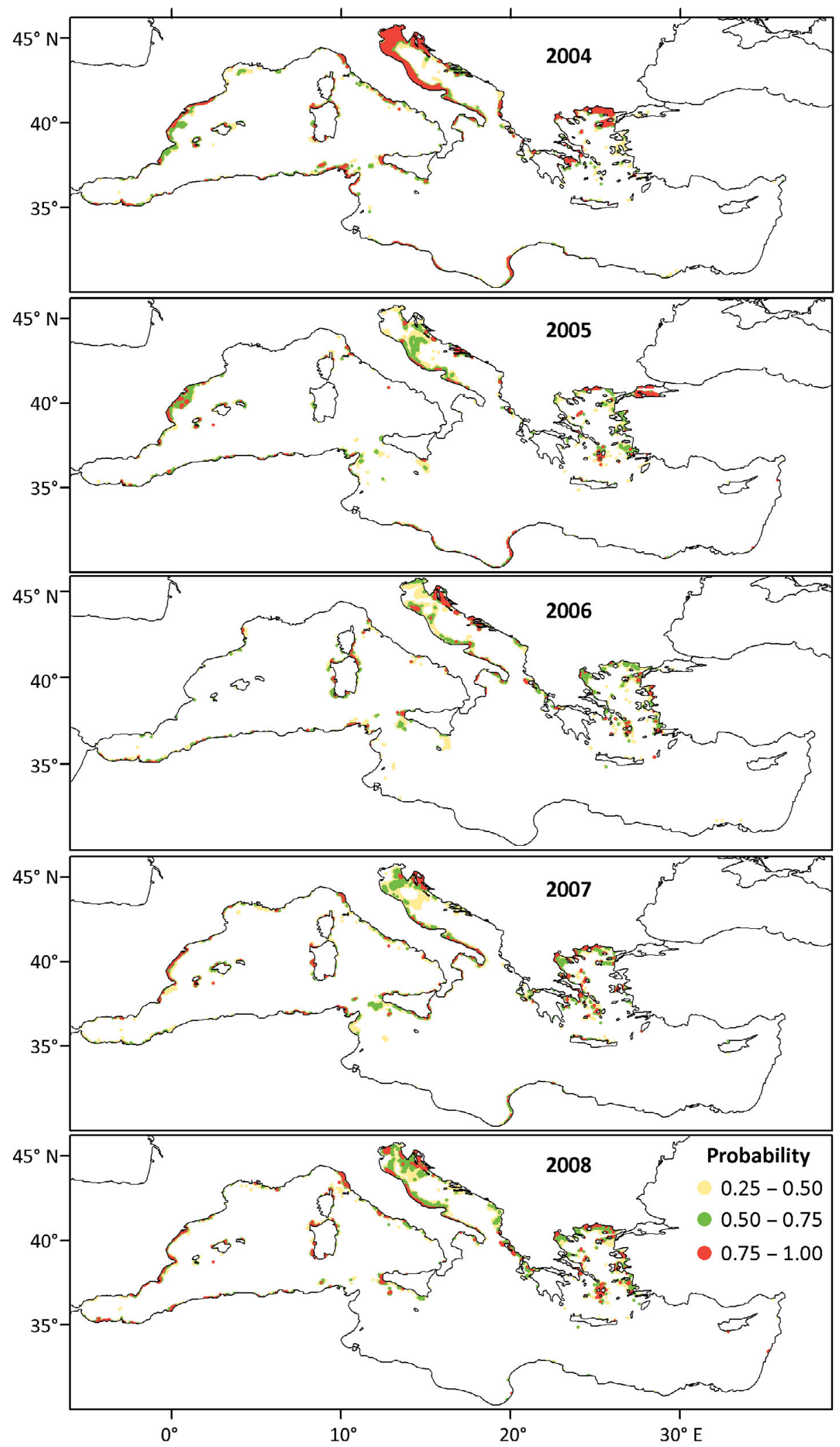

Fig. 5. Sardina pilchardus. Habitat suitability maps indicating the probability of sardine presence in the Mediterranean Sea in early autumn based on the estimated GAM model in September. Spatial resolution used for prediction was $4 \mathrm{~km}$ of mean monthly satellite values from September 2004 to 2008 


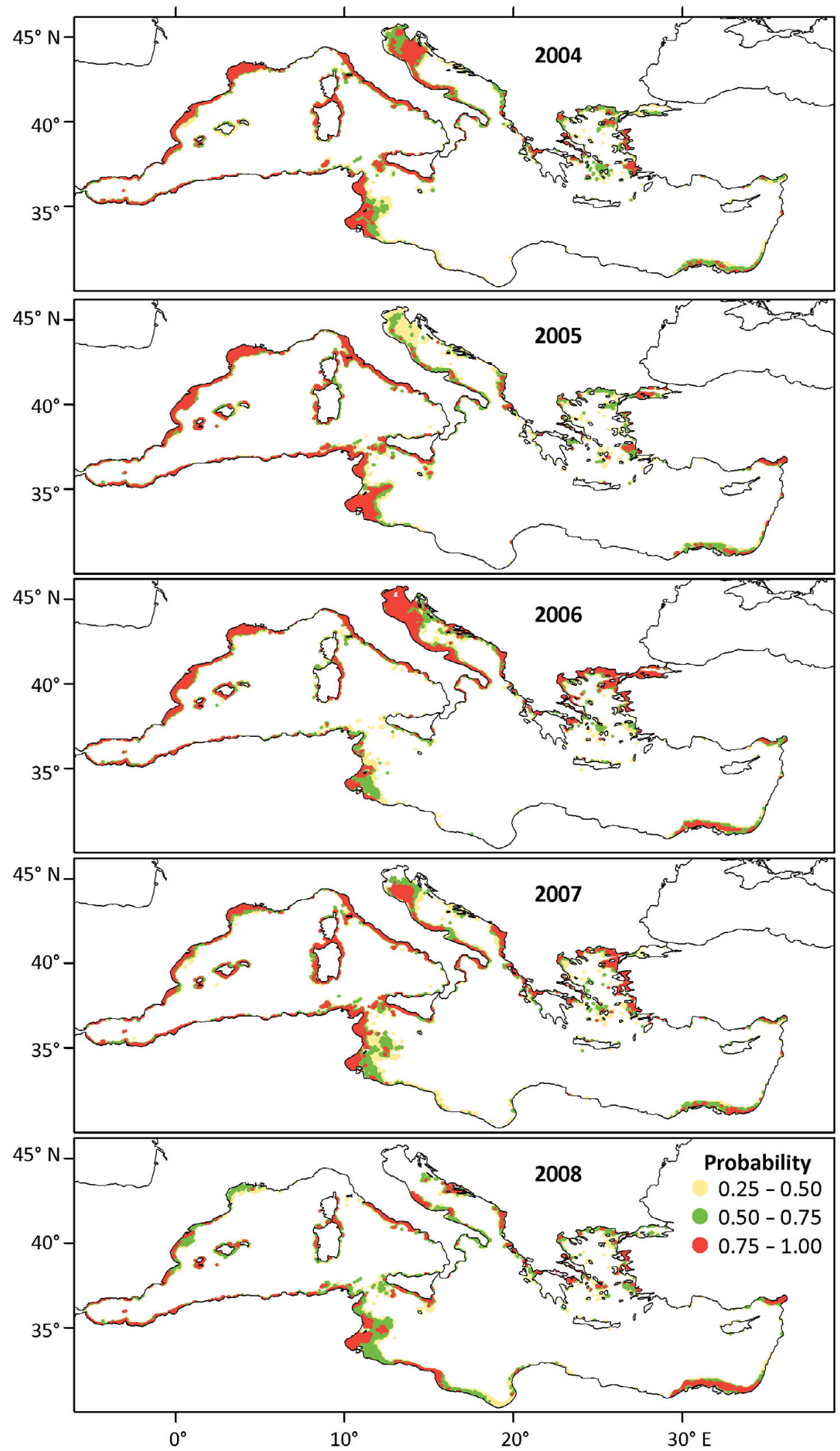

Fig. 6. Sardina pilchardus. Habitat suitability maps indicating the probability of sardine presence in the Mediterranean Sea in early winter based on the estimated GAM model in December. Spatial resolution used for prediction was $4 \mathrm{~km}$ of mean monthly satellite values from December 2004 to 2008 


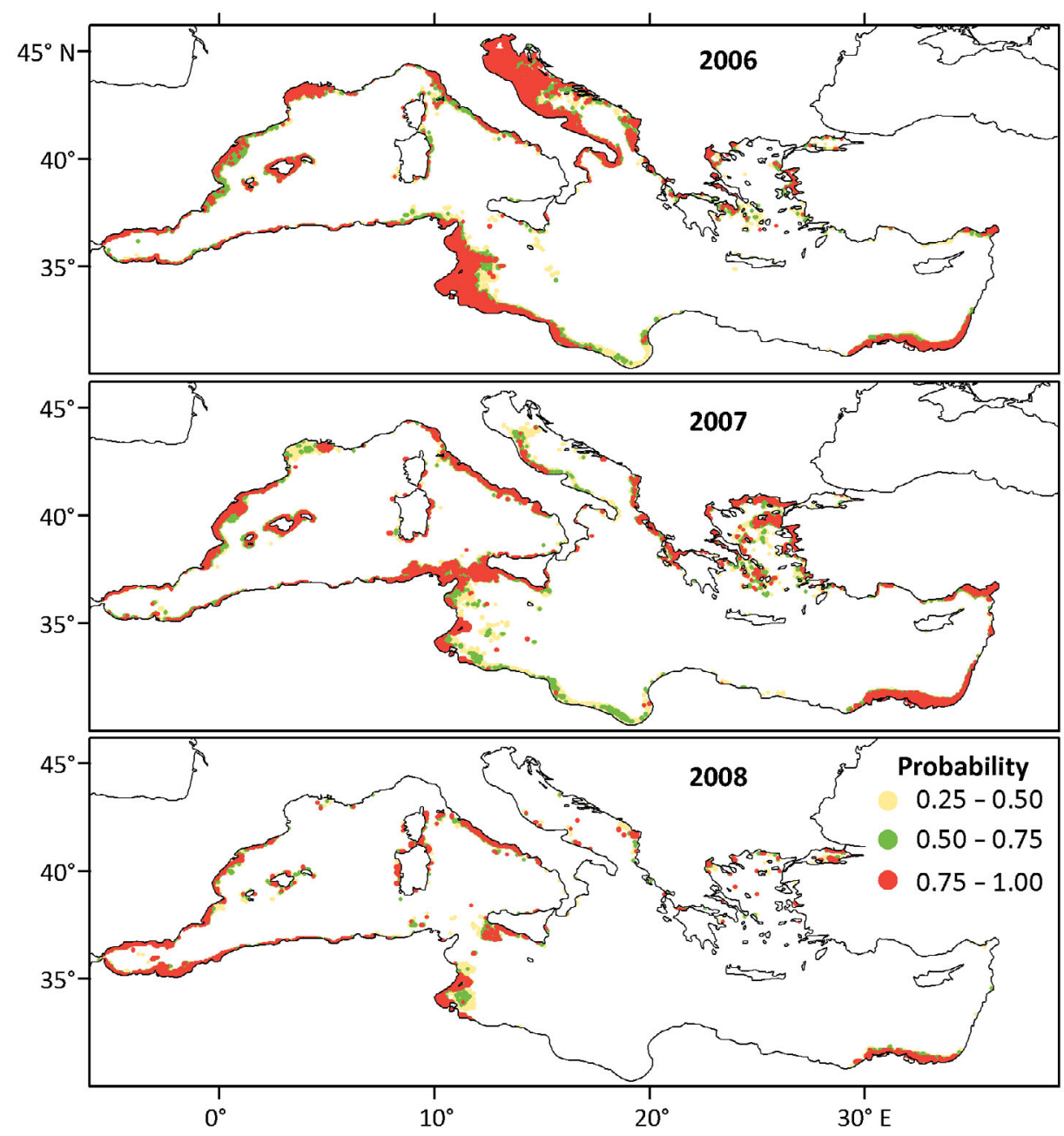

Fig. 7. Sardina pilchardus. Habitat suitability maps indicating the probability of egg presence in the Mediterranean Sea based on the estimated GAM model in December. Spatial resolution used for prediction was $4 \mathrm{~km}$ of mean monthly satellite values from December 2006 to 2008

\section{DISCUSSION}

Our objective was to use environmental associations in order to identify and map areas that could serve as adult habitat and spawning grounds of the European sardine in the Mediterranean Sea during 3 different seasons (i.e. early summer, early autumn and early winter). Data from the western (Spanish Mediterranean waters), the central (Adriatic Sea and Sicily Channel) and the eastern parts (North Aegean Sea) of the basin were used for this purpose for the first time. Moreover, scattered past information on the spatial distribution of sardine in the Mediterranean Sea was integrated within the current work to support the indicated suitable areas outside the study regions and periods.

Depth, SLA, SST and CHLA were the variables found to be influential in all seasons. Bottom depth and SST were the 2 variables that explained most of the variability in all models. However, SST was the main explicative variable during summer, whereas the bottom depth effect explained most of the variation during autumn and winter. Sardine showed a higher probability of being present in shallow waters (less than $65 \mathrm{~m}$ depth) during summer but exhibited a wider distribution, reaching deeper waters of up to $100 \mathrm{~m}$ deep in autumn and winter. SST was also important concerning the spawning sardine habitat during winter (i.e. eggs model).

During June, the model indicates that sardine tend to prefer shallow coastal waters characterised by mild SST values (i.e. $19^{\circ} \mathrm{C}$ to $22^{\circ} \mathrm{C}$ ). This is indicative of the gulfs and the closed basins of the North Aegean Sea where shallow waters dominate and river outflow and BSW inputs characterise these areas. BSW induces high hydrological complexity in the area, 


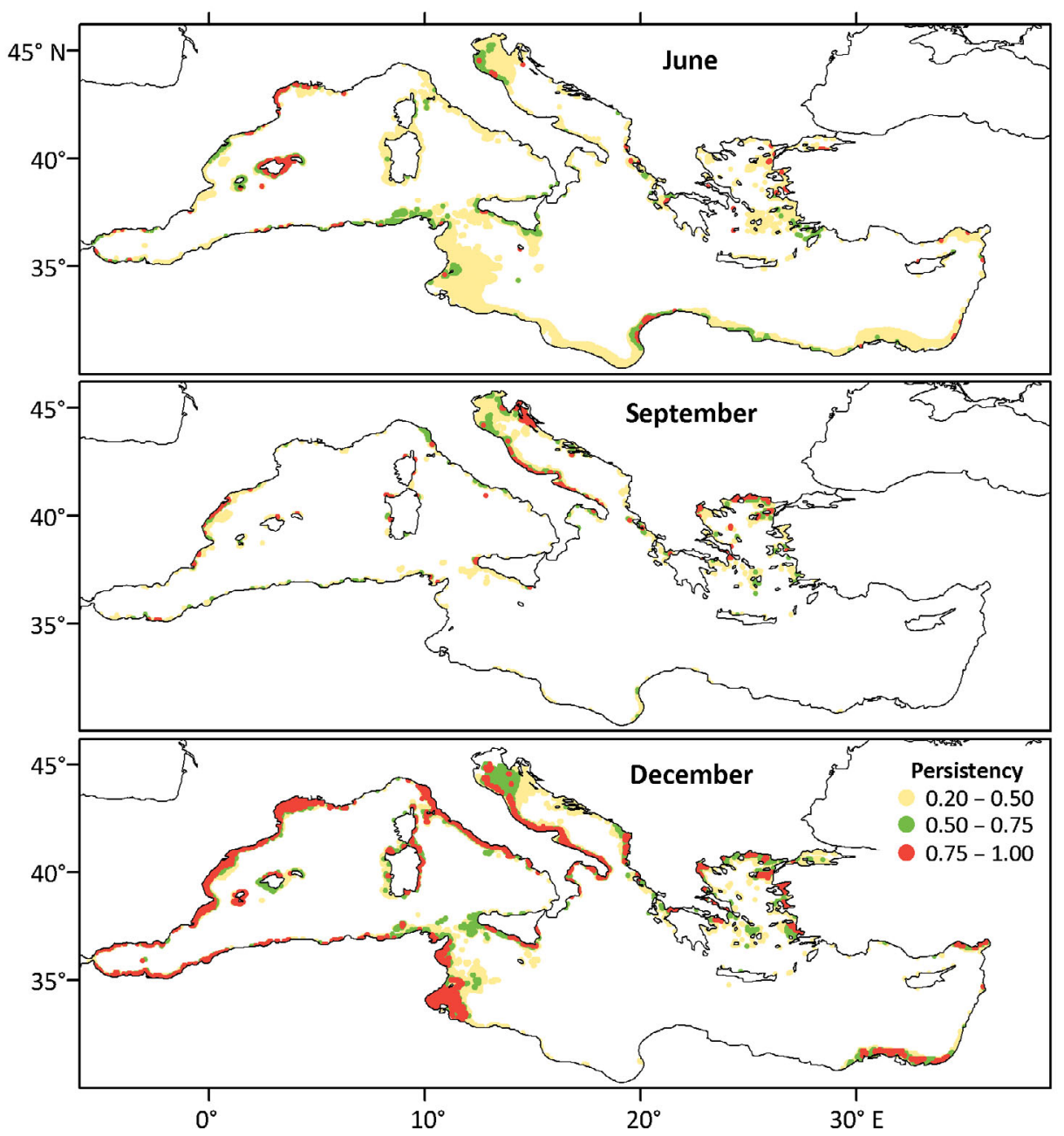

Fig. 8. Sardina pilchardus. Preferred habitat persistency indices (PI) for sardine in the Mediterranean Sea during June, September and December. Areas with low ( $\mathrm{PI}=0.20$ to 0.50$)$, medium (PI $=0.50$ to 0.75 ) and high persistency $(\mathrm{PI}>0.75)$ are shown in all cases

resulting in the formation of strong currents, fronts and anticyclonic systems that are permanent features during summer and are known to enhance local productivity (Isari et al. 2006, Somarakis \& Nikolioudakis 2007). These environmental preferences were also indicative of the coastal waters of the Sicily Channel, areas that are supported by local surveys in the early 2000s (Patti et al. 2004). In the Adriatic, suitability maps indicated that potential 'hot-spot' areas (i.e. areas with increased probability of sardine presence) presenting these environmental preferences were mainly located at the northern part of the basin in association with the wider Po River Delta region. These locations are largely supported by past survey data in the area (Tičina et al. 2000). In the central part of the Adriatic, potential 'hot-spot' areas of sardine were mainly located in the coastal waters of the eastern area, which is also supported by local landings
(Morello \& Arneri 2009 and references therein). In the Western Mediterranean, potential habitat areas were mainly identified in the coastal waters, being wider in extent when associated with the Rhone and the Ebro River area as well as in the Balearic Islands plateau. These areas generally agree with the distribution grounds of sardine population as indicated in recent acoustic summer surveys in the area (Anonymous 2009).

During early autumn, the respective model indicates a higher probability for sardine presence associated with a wider range of SST values (i.e. 20 to $26^{\circ} \mathrm{C}$ ) compared to summer when combined with coastal waters (up to $110 \mathrm{~m}$ depth), moderate upwelling (cyclonic) water movement and moderate CHLA values. In the Adriatic Sea, suitable areas seem to expand beyond the Po River Delta region compared to the summer period, covering most of the continental shelf in 


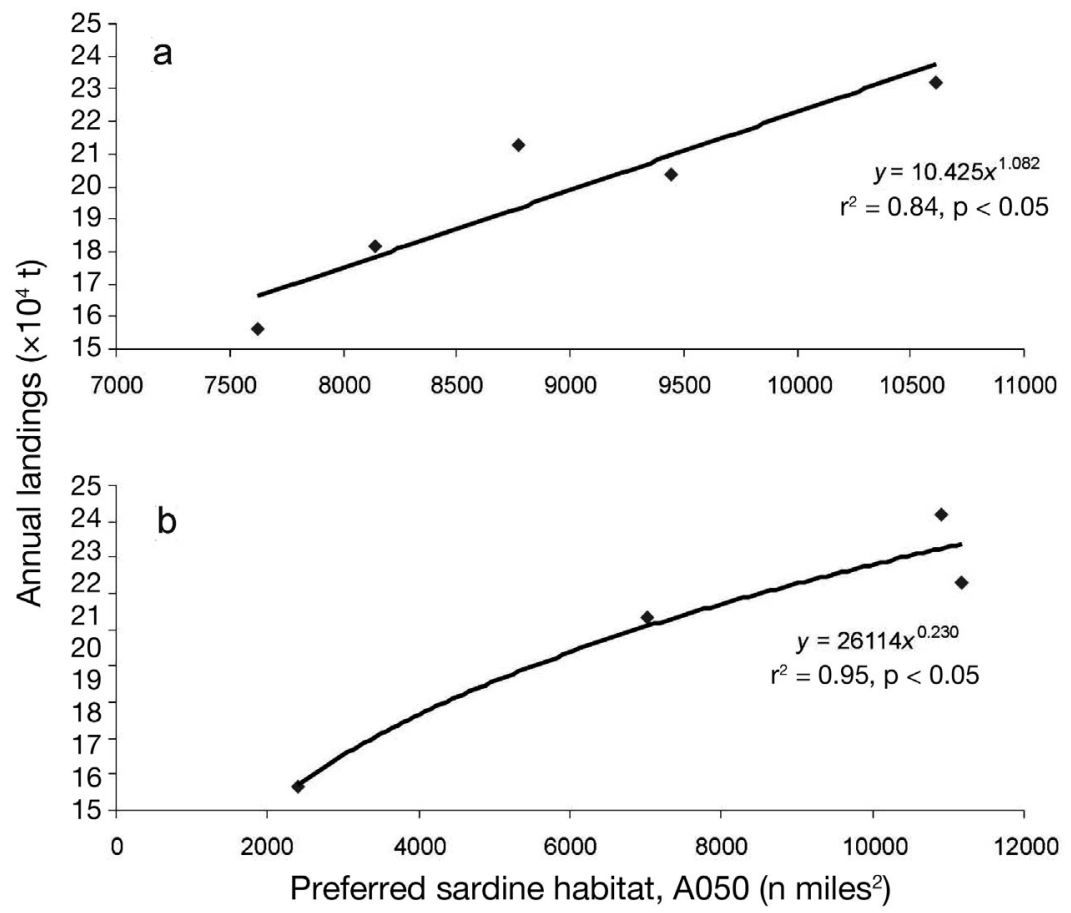

Fig. 9. Sardina pilchardus. Relationships between annual sardine landings and the extent of the preferred sardine habitat (A050 $=$ area presenting $>0.50$ probability of suitable environmental conditions for sardine presence) over the entire Mediterranean Sea in (a) December and (b) June with a 1 yr lag
The selected winter model also suggests a similar expansion of the preferred areas for the North Aegean and Adriatic Seas. Probability maps indicate high probabilities of suitable conditions inside the gulfs and the inshore waters of the North Aegean Sea. Predicted preferred sites are sustained by the known spawning grounds of sardine during early winter in the North Aegean during the late 1990s (Somarakis et al. 2006). Suitable areas cover most of the continental shelf of the North Adriatic, extending southward along the coastal waters of the western and the eastern parts of the basin, consistently covering the exterior part of the midDalmatian islands. This was also found by the recorded spatial distribution of the species in the Adriatic during the 1980's (Morello \& Arneri 2009 and references therein).

Summarising the seasonal patterns in the potential habitat of sardine an expansion of the preferred habitat areas from summer to winter in all the northern part of the basin. In the Central Adriatic, suitable habitats were detected along the coastal waters of the Italian peninsula as well as in the coastal zone of the eastern Adriatic, extending offshore around the exterior part of the mid-Dalmatian islands. Similarly, in the North Aegean Sea, an expansion of the potential habitat over the continental shelf was also indicated. No marked differences were observed in the Sicily Channel, whereas in the Western Mediterranean, potential habitat areas were similar to those in the summer period, although they did exhibit higher inter-annual variability. This was more pronounced in the areas indicated as preferred or most suitable for sardine presence.

During early winter in the Spanish Mediterranean waters, model results adequately describe the oceanographic complexity of the area. The study region comprises both an upwelling area, the Alboran Sea, as well as an area with extended continental shelf subjected to the outflow of the Ebro River. An expansion of the preferred areas during December was observed. Preferred areas indicated by the model were also verified by the results of past acoustic surveys (Abad et al. 1998, Iglesias et al. 2006) as well as the results of applied habitat models that were based on hydrographic data (Bellido et al. 2008). study areas, except for the Sicily Channel was consistently noticed. However, this habitat area expansion is not visible in the basin habitat (i.e. A025) nor in the 'hot-spot' areas (i.e. A075), but only in the preferred habitat (i.e. A050). Basin habitat does not differentiate because it represents more or less the wider distribution area of the species that remains constant throughout the year. 'Hot-spot' areas present low variability because they meet particular environmental conditions that enhance food availability throughout the year, forming the core nuclei of sardine habitat in the Mediterranean. This expansion in sardine preferred habitat from early summer to early winter is related to population characteristics and the seasonal migratory behaviour of sardine.

Sardines are known to spawn in the Mediterranean Sea mainly from October to April (e.g. Regner et al. 1987, Sinovčić 2001, Olivar et al. 2003, Somarakis et al. 2006, Ganias et al. 2007, Palomera et al. 2007). Therefore, during the early summer, the sardine population is a mixture of juveniles and adults, dominated by the young of the year. During autumn and winter, the fully recruited sardine population is known to perform migratory behaviour that serves spawning purposes. In large upwelling areas migration can be spatially long and extend offshore (e.g. 
California; Lynn 2003, Zwolinski et al. 2011), whereas in the coastal Atlantic waters (Furnestin \& Furnestin 1959, Stratoudakis et al. 2007, Bernal et al. 2007) and in the Adriatic (Morello \& Arneri 2009 and references therein) migration related to spawning is known to be restricted to up to $100 \mathrm{~m}$ depth, supporting the idea of coastal spawning. This also agrees with the expansion of sardine preferred habitat we noticed in the entire Mediterranean basin.

This expansion most likely reflects the peculiarities of the Mediterranean Sea, where suitable areas favouring growth, feeding and spawning processes tend to be localised. These processes are mostly associated with point sources of nutrients that enhance productivity locally like river runoffs or local upwelling. The existence of such limited suitable areas along with complex oceanographic and topographic characteristics (i.e. irregularities in the coastline and the bathymetry) are likely to prevent long distance migrations for sardine between spawning and juvenile grounds, as also indicated by Giannoulaki et al. 2011.

This is even more pronounced in the Sicily Channel, where no significant seasonal variation was shown. This region is characterised by a narrow continental shelf (15 $\mathrm{n}$ miles) that widens in the most eastern and most western parts, reaching $50 \mathrm{n}$ miles at the Malta shelf. This narrow continental shelf largely determines the available space and thus the potential habitat for a coastal species like sardine. The local sardine stock presents a fairly uniform distribution along the southern coast of Sicily but exhibits large inter-annual variability in abundance, varying by even more than $80 \%$ from year to year (Patti et al. 2004, SGMED 2009). This variability is linked to year-to-year variability of the AtlanticIonian Stream (AIS) that dominates the surface circulation in the area, affecting productivity, the extension of the upwelling and the formation of frontal structures (Cuttitta et al. 2003, Patti et al. 2004, 2010).

Suitable areas that could serve as sardine habitat in the Mediterranean were also indicated outside the study regions. In the Western Mediterranean these were identified in the Gulf of Lions and the coastal waters of the Ligurian Sea by the findings of past surveys in these areas (Gulf of Lions: Guennegan et al. 2000, Bigot 2007; Ligurian Sea: Romanelli \& Giovanardi 2000, Romanelli et al. 2002). Areas of increased probability were consistently shown along the North African coast, mainly in the extended continental shelf of the Gulf of Gabes in Tunisia and in the Nile Delta region during early summer. During the winter sardine potential habitat appears to be more ex- tended, also covering most of the Moroccan and Algerian coasts. These areas are verified by the known distribution and the fishing grounds of sardine along these coasts (Djabali et al. 1991, Ramzi et al. 2006, Bedairia \& Djebar 2009), the Tunisian and Libyan coastal waters as well as the Nile Delta region along the Egyptian coast (El-Haweet 2001, Ben Abdallah \& Gaamour 2005). Further east, the information on the spatial distribution of sardine in the Levantine basin is currently lacking. However, the composition of local landings suggests sardine presence in the area (Bariche et al. 2006, 2007, Gucu et al. 2010).

However, the lack of potential habitat areas along the North African coast and the Levantine during September is not supported by the information available from these regions (Zarrad et al. 2008). Therefore this picture was largely attributed to model deficiencies. September is a transitional season in which variables such as SST and CHLA can vary greatly between the different parts of the Mediterranean and especially between the northern and southern parts (Bosc et al. 2004, Lejeusne et al. 2010). In order to assess a habitat model applicable to the entire basin during the transition seasons (i.e. spring and autumn), including data from the southern and western parts of the Mediterranean Sea in the model is essential.

\section{Potential spawning habitat (PSH)}

The PSH of sardine during December was modelled using environmental variables for the first time in the Mediterranean, based on 3 years of egg data collected in Spanish Mediterranean waters. Sardine spawning is known to be related to temperature (e.g. Regner et al. 1987, Olivar et al. 2003, Stratoudakis et al. 2007, Ganias et al. 2007, Palomera et al. 2007). A higher probability for sardine egg presence was estimated for coastal waters with up to $110 \mathrm{~m}$ depth and SST values of 14 to $17^{\circ} \mathrm{C}$ when co-occuring with moderate CHLA values. This range of SST agrees with the known temperature preferences for sardine spawning in the Mediterranean Sea, where sardine are known to spawn when surface temperature falls well below $20^{\circ} \mathrm{C}$ (Olivar et al. 2003). Specifically, studies have shown a preference for temperatures of 12 to $14^{\circ} \mathrm{C}$, with spawning occurring up to $19^{\circ} \mathrm{C}$ in the Catalan Sea (Palomera et al. 2007), and a similar temperature range of 17 to $19^{\circ} \mathrm{C}$ during December in the Aegean Sea (Somarakis et al. 2006). In the Adriatic, the temperature preferences lie within 12 to $16^{\circ} \mathrm{C}$ according 
to studies carried out mainly in the 1970s and 1980s (Morello \& Arneri 2009 and references therein). During the 1990s, a study also indicated that sardines leave shallow areas of the most northern part of the Adriatic Sea when temperatures fall below $10.5^{\circ} \mathrm{C}$ (Tičina et al. 2000). Thus, the preferred range of SST indicated by the PSH model is likely to capture most of the variability between areas, supporting the use of the model to obtain a snapshot of sardine PSH for the entire Mediterranean basin.

In the Spanish Mediterranean waters, the indicated PSH areas are dominated by the narrow shelf of the North Alboran Sea, the Ebro River area, the Catalan Sea and the Balearic plateau, which matches the known sardine spawning grounds in the region (Pérez de Rubín 1996, Olivar et al. 2003, García et al. 2006, Vargas-Yáñez \& Sabatés 2007). These areas generally match those indicated by the adult model in December, verifying that the patchiness of the eggs closely reflects the patchiness of the spawning adults. A high probability of egg presence is also indicated for waters deeper than those of adults (i.e. $110 \mathrm{~m}$ versus $90 \mathrm{~m}$ ), which is justified by the passive transportation of eggs offshore with currents. Annual variation of the PSH in the North Alboran Sea is most likely associated with the variability of the local upwelling and the way it affects the circulation of the area (Pérez de Rubín 1996).

In the Adriatic, potential spawning grounds of sardine were indicated in the extended continental shelf of the North Adriatic as well as in the coastal waters of the western and the eastern parts (Morello \& Arneri 2009 and references therein). The sharp decrease in the indicated potential spawning ground at the northern part of the basin in 2007 and 2008 was due to the lack of satellite coverage of the area during the respective December period. In the Aegean and eastern Ionian Seas, potential spawning grounds were more persistent inside the coastal waters and the gulfs of the western part. Although the information concerning sardine spawning grounds in these areas is limited, the indicated areas generally coincide with the known spawning grounds of sardine during the early 2000's (Somarakis et al. 2006). No information is available on the spawning habitat of sardine in the Sicily Channel, but preferred spawning areas generally match the potential habitat of adults.

The spawning of sardine is known to be related to temperature and chlorophyll a concentration but it has also been related to bottom depth (Bernal et al. 2007, Planque et al. 2007, Ganias 2009). However, optimal temperature for spawning sardine seems to vary greatly between regions. In the Bay of Biscay and the Moroccan Atlantic waters, Atlantic sardine Sardinops pilchardus spawns in waters between 12.5 and $18.5^{\circ} \mathrm{C}$ (i.e. Ettahiri et al. 2003, Planque et al. 2007), while for Pacific sardine S. sagax in the California system, the temperature preferences varied from 11.5 to $17^{\circ} \mathrm{C}$ (i.e. Lynn 2003, Zwolinski et al. 2011). Our results suggest a preferential temperature range that is more similar to that of $S$. sagax in the Benguela upwelling system, which has a bimodal range including one major peak at 15.5 to $17.5^{\circ} \mathrm{C}$ and a secondary peak between 18.7 and $20.5^{\circ} \mathrm{C}$ (van der Lingen et al. 2001).

\section{Landings and potential habitat}

Based on 5 yr of available data, the annual variability in sardine landings for the entire Mediterranean Sea (FAO 2010) was found to be significantly related to the size of sardine preferred habitat areas (A050) during the summer of the previous year. This connection underlines the importance of the existence of suitable environmental conditions in determining the extent that nursery and feeding grounds can affect fish abundance in the following year. Moreover, the extent of the winter potential habitat or otherwise the extent of the spawning adult grounds is related to the landings (or indirectly to the fish abundance) of the same year. An increase in landings along with an increase in habitat extent could be explained in terms of sardine density-dependent behaviour. Sardines can expand their population along with an increase in the size of the habitat (Barange et al. 2009) and at the same time the greater the extent of the adult grounds, the more extended are the operation grounds of the fishery and the subsequent fisheries production. These associations imply that the extent of the potential habitat could be a candidate for the ecosystem spatial indicator, useful to monitoring the potential for fish stocks to expand or contract under climate forcing (Barange et al. 2009). Specifically, if this relationship between the habitat extent with landings or abundance estimates can be verified with additional years of data, then it could support the suggestion of an ecological, spatial indicator (sensu Woillez et al. 2009). This is of special importance for the Mediterranean basin, which is likely to become one of the regions most affected by the ongoing warming trend (Lejeusne et al. 2010) and our approach can take advantage of the results of acoustic surveys that are regularly held for the monitoring of small pelagic fish stocks beyond the standard stock assessment purposes (Koslow 2009). 


\section{Future perspectives}

Habitat suitability maps resulting from this work can provide large-scale essential species distribution information for environmental research, resource management, conservation planning, population viability analysis, environmental risk assessment and ecosystem modelling. The present study is the first attempt to construct such models on different life stages (e.g. eggs, adults) and integrate knowledge on how environmental variables affect the spatial distribution of these life stages. In a next step, conditioning these models with climate change scenarios would be of particular ecological interest in order to assess changes in the life cycle patterns driven by changes in climate.

In the case of small pelagic fish, habitat suitability maps can be a simple way to visualise possible changes in the state of the ecosystem that are reflected in the shrinkage and expansion of the suitable habitat for each species. This could comprise the basis for the development of indicators to spatially characterise the coastal Mediterranean ecosystems. From a management perspective, large-scale conservation planning requires the identification of priority areas in which species have a high likelihood of longterm persistence. Going further, examining the spatial and temporal overlapping of habitat maps can reveal predator-prey relationships (e.g. small pelagic and zooplankton, small pelagic and marine mammals) or competitive spatial patterns between species, thus providing essential information for an ecosystem approach to fisheries. Incorporating such knowledge into spatial dynamic models like Ecospace (Pauly et al. 2000) can eventually result in a very effective, highly dynamic management tool.

Acknowledgements. This study was supported by the Commission of the European Union through the Project MARIFISH: 'Strengthening the links between European marine fisheries science and fisheries management, Regional Scale Study-The Mediterranean' (6th FP/EU, Coordination action ERANET: ERAC-CT-2006-025989). We thank the captains and crews of the RVs 'Philia', 'Cornide de Saavedra', 'BIOS' and 'Dallaporta' as well as all of the scientists onboard for their assistance during the surveys. We also thank L. Ciannelli for his guidance on the application of GAMs as well as the 3 anonymous reviewers for their comments that helped us to improve our manuscript.

\section{LITERATURE CITED}

Abad R, Miquel J, Iglesias M, Álvarez F (1998) Acoustic estimation of abundance and distribution of sardine in the northwestern Mediterranean. Fish Res 34:239-245
Agenbag JJ, Richardson AJ, Demarcq H, Fréon P, Weeks S, Shillington FA (2003) Estimating environmental preferences of South African pelagic fish species using catch size- and remote sensing data. Prog Oceanogr 59:275-300

Alcamo J, Moreno JM, Nováky B, Bindi M and others (2007) Europe. In: Parry ML, Canziani OF, Palutikof JP, van der Linden PJ, Hanson CE (eds) Climate change 2007: impacts, adaptation and vulnerability. Contribution of Working Group II to the Fourth Assessment Report of the Intergovernmental Panel on Climate Change. Cambridge University Press, Cambridge, p 541-580

Allain G, Petitgas P, Lazure P, (2001) The influence of mesoscale ocean processes on anchovy (Engraulis encrasicolus) recruitment in the Bay of Biscay estimated with a three-dimensional hydrodynamic model. Fish Oceanogr 10:151-163

Anonymous (2009) Informe resultados campaña MEDIAS 0609. Iglesias M (ed) March 2010 Internal report. Instituto Español de Oceanografía, Madrid

Artegiani A, Bregant D, Paschini E, Pinardi N, Raicich F, Russo A (1997) The Adriatic Sea general circulation. Part I: air-sea interactions and water mass structure. J Phys Oceanogr 27:1492-1514

Austin MP (2002) Spatial prediction of species distribution: an interface between ecological theory and statistical modelling. Ecol Model 157:101-118

Bakun A (1996) Patterns in the ocean: ocean processes and marine population dynamics. California Sea Grant College System and Centro de Investigaciones Biológicas de Noroeste, La Paz, México

Barale V, Jaquet JM, Ndiaye M (2008) Algal blooming patterns and anomalies in the Mediterranean Sea as derived from the SeaWiFS data set (1998-2003). Remote Sens Environ 112:3300-3313

Barange M, Coetzee J, Takasuka A, Hill K, Gutierrez M, Oozeki Y, van der Lingen C, Agostini V (2009) Habitat expansion and contraction in anchovy and sardine populations. Prog Oceanogr 83:251-260

Barange M, Field JG, Harris RP, Hofmann EE, Perry RI, Werner FE (2010) Marine ecosystems and global change. Oxford University Press, New York, NY

Bariche M, Alwan N, El-Fadel M (2006) Structure and biological characteristics of purse seine landings off the Lebanese coast (eastern Mediterranean). Fish Res 82: 246-252

- Bariche M, Sadek R, Al-Zein MS, El-Fadel M (2007) Diversity of juvenile fish assemblages in the pelagic waters of Lebanon (eastern Mediterranean). Hydrobiologia 580: 109-115

> Barry S, Elith J (2006) Error and uncertainty in habitat models. J Appl Ecol 43:413-423

Basilone G, Guisande C, Patti B, Mazzola S, Cuttitta A, Bonanno A, Vergara AR, Maneiro I (2006) Effect of habitat conditions on reproduction of the European anchovy (Engraulis encrasicolus) in the Strait of Sicily. Fish Oceanogr 15:271-280

Bedairia A, Djebar AB (2009) A preliminary analysis of the state of exploitation of the sardine, Sardina pilchardus (Walbaum, 1792), in the gulf of Annaba, East Algerian. Anim Biodiversity Conserv 32:89-99

Behringer DW, Xue Y (2004) Evaluation of the global ocean data assimilation system at NCEP: the Pacific Ocean. 8th Symp Integrated Observing and Assimilation Systems for Atmosphere, Oceans, and Land Surface. Proc 84th Annu Meeting Am Meteorol Soc. American Meteorologi- 
cal Society, Boston, MA, p11-15

Bellido JM, Pierce GJ, Wang J (2001) Modelling intraannual variation in abundance of squid Loligo forbesi in Scottish waters using generalised additive models. Fish Res 52:23-39

Bellido JM, Brown AM, Valavanis VD, Giráldez A, Pierce GJ, Iglesias M, Palialexis A (2008) Identifying essential fish habitat for small pelagic species in Spanish Mediterranean waters. Hydrobiologia 612:171-184

$>$ Bellier E, Planque B, Petitgas P (2007) Historical fluctuations in spawning location of anchovy (Engraulis encrasicolus) and sardine (Sardina pilchardus) in the Bay of Biscay during 1967-73 and 2000-2004. Fish Oceanogr 16:1-15

Ben Abdallah L, Gaamour A (2005) Répartition géographique et estimation de la biomasse des petits pélagiques des côtes tunisiennes. MedSudMed Tech Doc 5:28-38

> Bernal M, Stratoudakis Y, Coombs S, Angelico MM and others (2007) Sardine spawning off the European Atlantic coast: characterization of and spatio-temporal variability in spawning habitat. Prog Oceanogr 74:210-227

- Bertrand A, Gerlotto F, Bertrand S, Gutiérrez M and others (2008) Schooling behaviour and environmental forcing in relation to anchoveta distribution: an analysis across multiple spatial scales. Prog Oceanogr 79:264-277

Bigot JL (2007) Stock assessment form regarding Sardina pilchardus in the Gulf of Lions (GSA07). Working paper, 8th Meeting of the Working Group on Small Pelagic Species, Sub-Committee on Stock Assessment, Scientific Advisory Committee. General Fisheries Commission for the Mediterranean, Athens

$>$ Bosc E, Bricaud A, Antoine D (2004) Seasonal and interannual variability in algal biomass and primary production in the Mediterranean Sea, as derived from 4 years of SeaWiFS observations. Global Biogeochem Cycles 18:GB1005 doi:10.1029/2003GB002034

Boyce MS, Vernier PR, Nielsen SE, Schmiegelow FKA (2002) Evaluating resource selection functions. Ecol Model 157:281-300

Castro LR, Fréon P, van der Lingen CD, Uriarte A (2005) Report of the SPACC meeting on small pelagic fish spawning habitat dynamics and the daily egg production method (DEPM). GLOBEC Report 22. GLOBEC International Project Office, Plymouth

Champalbert G (1996) Characteristics of zooplankton standing stock and communities in the Western Mediterranean Sea: relations to hydrology. Sci Mar 60(Suppl 2): 97-113

Chilès JP, Delfiner P (1999) Geostatistics: modelling spatial uncertainty, 2nd edn. Wiley Series in Probability and Statistics. John Wiley, New York, NY

> Coetzee JC, van der Lingen CD, Hutchings L, Fairweather TP (2008) Has the fishery contributed to a major shift in the distribution of South African sardine? ICES J Mar Sci 65:1676-1688

Coll M, Shannon LJ, Moloney CL, Palomera I, Tudela S (2006) Comparing trophic flows and fishing impacts of a NW Mediterranean ecosystem with coastal upwelling systems by means of standardized models and indicators. Ecol Model 198:53-70

> Colloca F, Bartolino V, Lasinio GJ, Maiorano L, Sartor P, Ardizzone G (2009) Identifying fish nurseries using density and persistence measures. Mar Ecol Prog Ser 381:287-296

Cury P, Bakun A, Crawford RJM, Jarre A, Quiñones R, Shannon LJ, Verheye HM (2000) Small pelagics in upwelling systems: patterns of interaction and structural changes in 'wasp-waist' ecosystems. ICES J Mar Sci 57:603-618

> Cuttitta A, Carini V, Patti B, Bonanno A and others (2003) Anchovy egg and larval distribution in relation to biological and physical oceanography in the Strait of Sicily. Hydrobiologia 503:117-120

Diniz-Filho JAF, Bini LM, Hawkins BA (2003) Spatial autocorrelation and red herrings in geographical ecology. Glob Ecol Biogeogr 12:53-64

Djabali F, Boudraa S, Bouhdid A, Bousbia H and others (1991) Travaux realises sur les stocks pelagiques et demersaux de la region de Beni-saf. FAO Fish Rep 447:160-170

El-Haweet A (2001) Catch composition and management of daytime purse seine fishery on the Southern Mediterranean Sea Coast, Abu Qir Bay, Egypt. Mediterr Mar Sci 2:119-126

Elith J, Graham CH, Anderson RP, Dudík M and others (2006) Novel methods improve prediction of species' distributions from occurrence data. Ecography 29:129-151

ESRI (Environmental Systems Research Institute) (1994) ARC macro language. ESRI Press, Redlands, CA, p 3-37

Ettahiri O, Berraho AM, Vidy G, Ramdani M, Do Chi T (2003) Observations on the spawning of Sardina and Sardinella off the south Moroccan Atlantic coast $\left(21-26^{\circ} \mathrm{N}\right)$. Fish Res 60:207-222

FAO (Food and Agriculture Organization) (2010) FishStat Plus: universal software for fishery statistical time series, Version 2.3. FAO Fisheries Department, Fishery Information, Data and Statistics Unit, Rome, www.fao.org/ fishery/statistics/software/fishstat

Foote KG, Knudsen HP, Vestnes G, MacLennan DN, Simmonds EJ (1987) Calibration of acoustic instruments for fish density estimation: a practical guide. ICES Coop Res Rep 144

Fortin MJ, Dale MRT (2005) Spatial analysis: a guide for ecologists. Cambridge University Press, Cambridge

Franklin J (2009) Mapping species distributions. Spatial inference and prediction. Cambridge University Press, New York, NY

Furnestin J, Furnestin ML (1959) La reproduction de la sardine et de l'anchois des côtes Atlantiques de Maroc (saisons et aires de ponte). Rev Trav Inst Pêch Marit 23: 79-104

> Ganias K (2009) Linking sardine spawning dynamics to environmental variability. Estuar Coast Shelf Sci 84:402-408

> Ganias K, Somarakis S, Koutsikopoulos C, Machias A (2007) Factors affecting the spawning period of sardine in two highly oligotrophic Seas. Mar Biol 151:1559-1569

García A, Cortés D, Ramírez T, Guisande C and others(2006) Field comparison of sardine post-flexion larval growth and biochemical composition from three sites in the $\mathrm{W}$ Mediterranean (Ebro river coast, bays of Almería and Málaga). Sci Mar 70(Suppl 2):79-91

Giannoulaki M, Machias A, Valavanis V, Somarakis S, Palialexis A, Tsagarakis K, Papaconstantinou C (2007) Spatial modeling of the European sardine habitat in the Eastern Mediterranean basin using GIS tools. Proc 38th CIESM Congress. Rapp Comm Int Mer Mediter 38:486

Giannoulaki M, Valavanis VD, Palialexis A, Tsagarakis K, Machias A, Somarakis S, Papaconstantinou C (2008) Modelling the presence of anchovy Engraulis encrasicolus in the Aegean Sea during early summer, based on satellite environmental data. Hydrobiologia 612:225-240

Giannoulaki M, Pyrounaki MM, Liorzou B, Leonori I and others (2011) Habitat suitability modelling for sardine (Sardina pilchardus) juveniles in the Mediterranean Sea. 
Fish Oceanogr 20:367-382

Gücü AC, Ok M, Sakman S (2010) Past and present of fish fauna in the NE Levant Sea and factors facilitating the colonization of Lessepsian fishes. FAO-EastMed Tech Doc 4:88-108

Guennegan Y, Liorzou B, Bigot JL (2000) Exploitation des petites pelagique dans le Golf du Lion et suivi de l'evolution des stocks par echo-integration de 1999 a 2000. 1st Session of the Working Group on Small Pelagic Species, Sub-Committee for Stock Assessment, Scientific Advisory Committee. General Fisheries Commission for the Mediterranean, Rome

Guisan A, Zimmermann NE (2000) Predictive habitat distribution models in ecology. Ecol Model 135:147-186

> Guisan A, Edwards TC Jr, Hastie T (2002) Generalized linear and generalized additive models in studies of species distributions: setting the scene. Ecol Model 157:89-100

- Hanley JA, McNeil BJ (1982) The meaning and use of the area under a receiver operating characteristic (ROC) curve. Radiology 143:29-36

Hastie T, Tibshirani R (1990) Generalized additive models. Chapman \& Hall, London

Iglesias M, Miquel J, Oñate D, Giraldez A, Díaz N, Tugores P (2006) ECOMED acoustic surveys: methodology, results and scope. 8th Session of the Working Group on Small Pelagic Species, Sub-Committee for Stock Assessment, Scientific Advisory Committee. General Fisheries Commission for the Mediterranean, Rome

Isari S, Ramfos A, Somarakis S, Koutsikopoulos C, Kallianiotis A, Fragopoulu N (2006) Mesozooplankton distribution in relation to hydrology of the Northeastern Aegean Sea, Eastern Mediterranean. J Plankton Res 28:241-255

> Jiménez-Valverde A, Lobo JM, Hortal J (2008) Not as good as they seem: the importance of concepts in species distribution modelling. Diversity Distrib 14:885-890

> Katsanevakis S, Maravelias CD, Damalas D, Karageorgis AP, Tsitsika EV, Anagnostou C, Papaconstantinou C (2009) Spatiotemporal distribution and habitat use of commercial demersal species in the eastern Mediterranean Sea. Fish Oceanogr 18:439-457

Koslow JA (2009) The role of acoustics in ecosystem-based fishery management. ICES J Mar Sci 66:966-973

> Leathwick JR, Elith J, Francis MP, Hastie T, Taylor P (2006) Variation in demersal fish species richness in the oceans surrounding New Zealand: an analysis using boosted regression trees. Mar Ecol Prog Ser 321:267-281

Lejeusne C, Chevaldonné P, Pergent-Martini C, Boudouresque $C F$, Pérez T (2010) Climate change effects on a miniature ocean: the highly diverse, highly impacted Mediterranean Sea. Trends Ecol Evol 25:250-260

Leonori I, Azzali M, De Felice A (2007) Assessment of small pelagic fish by acoustic methods in north western Adriatic Sea. Working Document, 8th Meeting of the Working Group on Small Pelagic Species, Sub-Committee on Stock Assessment, Scientific Advisory Committee. General Fisheries Commission for the Mediterranean, Athens

Lleonart J, Maynou F (2003) Fish stock assessments in the Mediterranean: state of the art. Sci Mar 67(Suppl 1): 37-49

- Lobo JM, Jiménez-Valverde A, Real R (2008) AUC: a misleading measure of the performance of predictive distribution models. Glob Ecol Biogeogr 17:145-151

> Lynn RJ (2003) Variability in the spawning habitat of Pacific sardine (Sardinops sagax) off southern and central California. Fish Oceanogr 12:541-553
Machias A, Stergiou KI, Somarakis S, Karpouzi VS, Kapantagakis A (2008) Trends in trawl and purse seine catch rates in the north-eastern Mediterranean. Mediterr Mar Sci 9:49-65

> Mackinson S, Nøttestad L, Guénette S, Pitcher T, Misund OA, Fernö A (1999) Cross-scale observations on distribution and behavioural dynamics of ocean feeding Norwegian spring-spawning herring (Clupea harengus L.). ICES J Mar Sci 56:613-626

> Marini M, Jones BH, Campanelli A, Grilli F, Lee CM (2008) Seasonal variability and Po River plume influence on biochemical properties along western Adriatic coast. J Geophys Res 113:C05S90

> Millot C (1990) The Gulf of Lions' hydrodynamics. Cont Shelf Res 10:885-894

Morello EB, Arneri E (2009) Anchovy and sardine in the Adriatic Sea-an ecological review. Oceanogr Mar Biol Annu Rev 47:209-256

Olivar MP, Catalán IA, Emelianov M, Fernández de Puelles ML (2003) Early stages of Sardina pilchardus and environmental anomalies in the Northwestern Mediterranean. Estuar Coast Shelf Sci 56:609-619

> Palomera I, Olivar MP, Salat J, Sabatés A, Coll M, García A, Morales-Nin B (2007) Small pelagic fish in the NW Mediterranean Sea: an ecological review. Prog Oceanogr 74: 377-396

Patti B, Bonanno A, Basilone G, Goncharov S and others (2004) Interannual fluctuations in acoustic biomass estimates and in landings of small pelagic fish populations in relation to hydrology in the Strait of Sicily. Chem Ecol 20: 365-375

> Patti B, Guisande C, Bonanno A, Basilone G, Cuttitta A, Mazzola S (2010) Role of physical forcings and nutrient availability on the control of satellite-based chlorophyll a concentration in the coastal upwelling area of the Sicilian Channel. Sci Mar 74:577-588

Pauly D, Christensen V, Walters C (2000) Ecopath, Ecosim, and Ecospace as tools for evaluating ecosystem impact of fisheries. ICES J Mar Sci 57:697-706

Pérez de Rubín J (1996) El ictioplancton del mar de Alborán. Relación de su distribución espacio-temporal y composición, con diferentes variables ambientales y con la distribución de los peces adultos. PhD thesis, University of Málaga

Phillips SJ, Anderson RP, Schapire RE (2006) Maximum entropy modeling of species geographic distributions. Ecol Model 190:231-259

> Planque B, Bellier E, Lazure P (2007) Modelling potential spawning habitat of sardine (Sardina pilchardus) and anchovy (Engraulis encrasicolus) in the Bay of Biscay. Fish Oceanogr 16:16-30

Pujol MI, Larnicol G (2005) Mediterranean sea eddy kinetic energy variability from 11 years of altimetric data. J Mar Syst 58:121-142

R Development Core Team (2009) R: a language and environment for statistical computing. R Foundation for Statistical Computing, Vienna. Available online at www.R-project.org

> Ramzi A, Hbid ML, Ettahiri O (2006) Larval dynamics and recruitment modelling of the Moroccan Atlantic coast sardine (Sardina pilchardus). Ecol Model 197:296-302

Regner S, Regner D, Marasovi I, Kršini F (1987) Spawning of sardine, Sardina pilchardus (Walbaum, 1972), in the Adriatic under upwelling conditions. Acta Adriat 28: $161-198$ 
Romanelli M, Giovanardi O (2000) A special fishery aimed at advanced larvae of Sardina pilchardus (Walbaum) along the northwestern and central western coasts of Italy: a general report. Biol Mar Mediterr 7:158-172

Romanelli M, Colloca F, Giovanardi O (2002) Growth and mortality of exploited Sardina pilchardus (Walbaum) larvae along the western coast of Italy. Fish Res 55:205-218

Russo A, Coluccelli A, Iermano I, Falcieri F and others (2009) An operational system for forecasting hypoxic events in the northern Adriatic Sea. Geofizika 26:191-213

Sacau M, Pierce GJ, Wang J, Arkhipkin AI and others (2005) The spatio-temporal pattern of Argentine shortfin squid Illex argentinus abundance in the southwest Atlantic. Aquat Living Resour 18:361-372

Segurado P, Araújo MB, Kunin WE (2006) Consequences of spatial autocorrelation for niche-based models. J Appl Ecol 43:433-444

SGMED (Subgroup on the Mediterranean Sea) (2009) Report of the SGMED-09-02 working group on the Mediterranean Part I. Scientific, Technical and Economic Committee for Fisheries. European Commission, Luxembourg

SGMED (2010) Report of the SGMED-10-02 working group on the Mediterranean Part I. Scientific, Technical and Economic Committee for Fisheries. European Commission, Luxembourg

Simmonds J, MacLennan D (2005) Fisheries acoustics, theory and practice, 2nd edn. Blackwell Publishing, Oxford

Sinovčić G (2001) Biotic and abiotic factors influencing sardine, Sardina pilchardus (Walb.) abundance in the Croatian part of the Eastern Adriatic. AdriaMed Tech Doc 3: 82-86

Smith WHF, Sandwell DTS (1997) Global sea floor topography from satellite altimetry and ship depth soundings. Science 277:1956-1962

Somarakis S, Nikolioudakis N (2007) Oceanographic habitat, growth and mortality of larval anchovy (Engraulis encrasicolus) in the northern Aegean Sea (eastern Mediterranean). Mar Biol 152:1143-1158

Somarakis S, Drakopoulos P, Filippou V (2002) Distribution and abundance of larval fish in the northern Aegean Sea - eastern Mediterranean - in relation to early summer oceanographic conditions. J Plankton Res 24:339-357

Somarakis S, Ganias K, Siapatis A, Koutsikopoulos C, Machias A, Papaconstantinou C (2006) Spawning habitat and daily egg production of sardine (Sardina pilchardus) in the eastern Mediterranean. Fish Oceanogr 15:281-292

> Stratoudakis Y, Coombs S, de Lanzós AL, Halliday N and others (2007) Sardine (Sardina pilchardus) spawning seasonality in European waters of the northeast Atlantic. Mar Biol 152:201-212

Tetko IV (2002) Neural network studies. 4. Introduction to associative neural networks. J Chem Inf Comput Sci 42: 717-728

Tičina V, Kačić I, Cetinić P (1999) Two-boat mid-water trawling on the northern Adriatic Sea. In: Ceronik E, Swiniarski J (eds) Proc Int Symp Responsible Fisheries \& Fishing Techniques, Ińsko, 16-19 June 1999. Faculty of Food Sciences and Fisheries, University of Agriculture,

Editorial responsibility: Konstantinos Stergiou, Thessaloniki, Greece
Szczecin, p 267-274

Tičina V, Ivančić I, Emrić V (2000) Relation between the hydrographic properties of the northern Adriatic Sea water and sardine (Sardina pilchardus) population schools. Period Biol 102(Suppl 1):181-192

Tičina V, Katavić I, Dadić V, Marasović I and others (2006) Acoustic estimates of small pelagic fish stocks in the eastern part of Adriatic Sea. Biol Mar Mediterr 13:124-136

Tsagarakis K, Machias A, Somarakis S, Giannoulaki M, Palialexis A, Valavanis VD (2008) Habitat discrimination of juvenile sardines in the Aegean Sea using remotely sensed environmental data. Hydrobiologia 612:215-223

> Twatwa NM, van der Lingen CD, Drapeau L, Moloney CL, Field JG (2005) Characterising and comparing the spawning habitats of anchovy Engraulis encrasicolus and sardine Sardinops sagax in the southern Benguela upwelling ecosystem. Afr J Mar Sci 27:487-499

Valavanis VD, Georgakarakos S, Kapantagakis A, Palialexis A, Katara I (2004) A GIS environmental modelling approach to essential fish habitat designation. Ecol Model 178:417-427

- Valavanis VD, Pierce GJ, Zuur AF, Palialexis A, Saveliev A, Katara I, Wang J (2008) Modelling of essential fish habitat based on remote sensing, spatial analysis and GIS. Hydrobiologia 612:5-20

van der Lingen CD, Hutchings L, Merkle D, van der Westhuizen JJ, Nelson J (2001) Comparative spawning habitats of anchovy (Engraulis capensis) and sardine (Sardinops sagax) in the southern Benguela upwelling ecosystem. In: Kruse GH, Bez N, Booth A, Dorn MW and others (eds) Spatial processes and management of marine populations. University of Alaska Sea Grant, Fairbanks, p 185-209

Vargas-Yáñez M, Sabatés A (2007) Mesoscale high-frequency variability in the Alboran Sea and its influence on fish larvae distributions. J Mar Syst 68:421-438

Weber ED, McClatchie S (2010) Predictive models of northern anchovy Engraulis mordax and Pacific sardine Sardinops sagax spawning habitat in the California Current. Mar Ecol Prog Ser 406:251-263

Woillez M, Rivoirard J, Petitgas P (2009) Notes on surveybased spatial indicators for monitoring fish populations. Aquat Living Resour 22:155-164

Wood SN (2006) Generalized additive models, an introduction with R. Chapman \& Hall, London

Zarrad R, Missaoui H, Alemany F, Hamza A and others (2008) Distribution and abundance of early life stages of Sardina pilchardus in the Gulf of Tunis (Central Mediterranean Sea) in relation to environmental and biological factors. Sci Mar 72:299-309

Zervakis V, Georgopoulos D (2002) Hydrology and circulation in the North Aegean Sea throughout 1997 and 1998. Mediter Mar Sci 3:5-19

Zwolinski JP, Oliveira PB, Quintino V, Stratoudakis Y (2010) Sardine potential habitat and environmental forcing off western Portugal. ICES J Mar Sci 67

Zwolinski JP, Emmet RL, Demer DA (2011) Predicting habitat to optimize sampling of Pacific sardine (Sardinops sagax). ICES J Mar Sci 68:867-879

Submitted: July 26, 2010; Accepted: August 26, 2011

Proofs received from author(s): December 6, 2011 